\title{
Soil morphological control on saline and freshwater lake hydrogeochemistry in the Pantanal of Nhecolândia, Brazil
}

\author{
L. Barbiero ${ }^{1,2}$, A. Rezende Filho ${ }^{3,4}$, S.A.C. Furquim ${ }^{4}$, S. Furian ${ }^{4}$, A.Y. Sakamoto ${ }^{5}$, V. Valles ${ }^{6}$, \\ R. C. Graham ${ }^{7}$, M. Fort ${ }^{8}$, R.P.D. Ferreira ${ }^{4}$, J.P. Queiroz Neto ${ }^{4}$ \\ 1 - Université de Toulouse; UPS (SVT-OMP); LMTG; 14 Av, Edouard Belin, F-31400 Toulouse, France \\ 2 - IRD; LMTG; F-31400 Toulouse, France \\ 3 - UFMS, Departamento de Geografia, Campus de Nova Andradina, Av. Eurico Soares Andrade 1020, \\ 79750-000, Nova Andradina-MS, Brazil \\ 4 - Laboratório de Pedologia, Departamento de Geografia, Universidade de São Paulo C.P. 8105, 05508-900, \\ São Paulo, Brazil \\ 5 - UFMS, Departamento de Geografia, Campus de Três Lagoas, Av. Ranulfo Marques Leal 3484, 79600-000, \\ Três Lagoas-MS, Brazil \\ 6 - Laboratoire d'Hydrogéologie, Université d'Avignon et des Pays du Vaucluse, 74 rue Louis Pasteur, 84029 \\ Avignon Cedex 01, France. \\ 7 - Soil and Water Sciences Program, Department of Environmental Sciences, University of California, \\ Riverside, CA 92521-0424, USA \\ 8 - UMR 8586 PRODIG, UFR G.H.S.S., Université Denis-Diderot (Paris 7), Case 70012 Place Jussieu F75251 \\ PARIS Cedex 05, France
}

Contact : barbiero@1mtg.obs-mip.fr

\begin{abstract}
:
Joint pedological, geochemical, hydrological and geophysical investigations were performed to study the coexistence of saline and freshwater lakes in close proximity and similar climatic conditions in the Nhecolândia region, Pantanal wetlands in Brazil. The saline lakes are concentrically surrounded by green sandy loam horizons, which cause differential hydrological regimes.

Mg-calcite, K-silicates, and amorphous silica precipitate in the soil cover, whereas $\mathrm{Mg}$ silicates and more soluble Na-carbonates are concentrated in the topsoil along the shore of the saline lake. In saline solutions, some minor elements (As, Se) reach values above the water quality recommendations, whereas others are controlled and incorporated in solid phases $(\mathrm{Ba}$, Sr). Locally, the destruction of the sandy loam horizons generates very acidic soil solution $(\mathrm{pH} \sim 3.5)$ through a process not yet understood. The soil distributions indicate that some
\end{abstract}


freshwater lakes are former saline lakes. They are invaded by freshwater after destruction of the sandy loam green horizons, then the freshwater becomes enriched in $\mathrm{K}^{+}, \mathrm{SO}_{4}{ }^{2-}, \mathrm{Fe}, \mathrm{Al}$, and a stream of minor and trace elements. The formation of these green sandy loam horizons in the saline environment and their destruction in the non-saline one emphasizes the dynamic nature of this environment.

Key words: Alkalinity, sodicity, saline lake, soil hydrology, Nhecolândia, Pantanal, Brazil.

\section{Introduction}

Wetlands and inundation plains play a major part in controlling river dynamics, including flooding, sedimentation, evaporation or infiltration of water, changes in aquatic chemistry, and biogeochemical processes related to redox conditions. They are often the seat of decontamination processes (denitrification) or production of greehouse gases $\left(\mathrm{N}_{2} \mathrm{O}, \mathrm{CH}_{4}\right)$. Permanent or seasonal wetlands also serve as major breeding grounds for waterfowl species and support a large ecological diversity.

The Pantanal wetland, located in the centre of the South American continent, and mainly in Brazil (Fig.1), is considered the world's largest wetland (Por, 1995). Although research in this region has recently increased, still very little is known about the functioning of the Pantanal ecosystem. Neglecting the understanding of its functioning could lead to misuse and, hence, harmful consequences.

The Pantanal wetland area is drained by the Paraguay river and its tributaries, most of them on the left bank of the Paraguay river. It is not a homogeneous system, but is actually composed of several sub-regions, which are often geomorphologically contrasting (Fig. 2). A peculiarity of the Nhecolândia, where our study was conducted, is the presence of thousands of both saline and freshwater round or elongated shaped lakes (Fig. 2) (Cunha, 1943; Brum and Souza 1985; Mourão et al., 1988). The genesis of these lakes is still under debate. One hypothesis claims that the lake formation occurred due to shifting of river courses. The lakes would then result from depressions surrounded by cut-off meander banks. Similarly, banks with short-cut meanders would turn into elongated sand ribbon, as suggested by Wilhelmy (1958) and later corroborated by Ab'Saber (1988). Another hypothesis suggests wind deflation in combination with high salinity of soils (Almeida and Lima, 1956) and accumulation of sand-size particles into 'Sebkha' type dunes (Tricart, 1982). Klammer (1982) conceded that this is only a partial explanation, since some areas show paleodunes without accompanying lakes. Aeolian reworking was suggested by Almeida (1945) to explain 
the grain size distribution of sands in the Nhecolândia area. Soares et al. (2003) and Assine and Soares (2004) emphasized that the sand size is very selective but both size and aeolian features could have been inherited from the source area. Moreover, no depositional features of these paleodunes have ever been identified in the soils (Colinvaux et al. 2000). Eiten (1983) took a different approach and attributed the genesis of the lakes to a karstic or pseudokarstic system. In all these studies, the presence of salts is attributed to an old phenomenon and, in particular, to the alternations of wet and arid phases during the Pleistocene (Ab'Saber 1988). Klammer (1982) even proposed the term 'paleodesert' to explain the presence of salty terminal lakes. However, the assumption of a former arid climate during the Late Pleistocene has not been confirmed by palynological data obtained in the Pantanal and surrounding areas, and is questioned today (Colinvaux et al. 2000). Several studies in neighbouring Central Brazil have suggested a colder and more humid paleoclimate during parts of the glacial period from 40,000 to 27,000 years B.P. (Ledru et al., 1996; Ferraz-Vicentini and SalgadoLabouriau, 1996). So, even the climatic conditions that could have favoured such landforms are questioned.

More recently, it was shown that all the waters of this region belong to the same chemical family (Barbiero et al., 2002) and that the changes observed in the chemical composition (major elements) result from salt precipitation associated with the concentration process. Therefore, the saline lakes could arise from the present-day concentration of lowsalinity waters that supply the Pantanal area each year. Although the lakes are subjected to the same amount of rainfall and evaporation, they developed different salinities. We propose that the explanation may be found in the local hydrological regime of these lakes, together with the associated hydrogeochemical processes. This study is therefore directed towards understanding the flow of water and its solutes between adjacent lakes.

\section{Site}

The Pantanal wetland is situated between $16^{\circ}$ and $20^{\circ} \mathrm{S}$ and $58^{\circ}$ and $55^{\circ} \mathrm{W}$, with a total area of about 200,000 $\mathrm{km}^{2}$ of which 140,000 $\mathrm{km}^{2}$ is located in Brazil (Fig. 1). The origin of the tectonic depression of the Pantanal basin was a consequence of reactivation of the forebulge associated with the Chaco foreland basin, during the last Andean compressive event at about 2.5Ma (Ussami et al., 1999). The vast Pantanal plain provides a gigantic natural flood control device for the storm waters resulting from torrential rainfall occurring during the wet period at the boundary between the Paraguay and Amazon basin. Each year, the heavy tropical rains cause the overflow of the main tributaries supplying the Pantanal. 
With the flood, the depressions are inundated and form extensive lakes, which coalesce into larger waterbodies. During the dry season, the floodwaters recede, resulting in a complex mosaic of grasslands and forests dotted with countless lakes and marshes. Put together, the ecological sub-regions (river corridors, gallery forests, perennial wetlands and lakes, seasonally flooded grasslands, terrestrial forests) form a large and biologically diverse ecosystem (Gottgens et al., 1998).

Part of the Pantanal wetland is developed on the Taquari megafan (Fig. 2), one of the largest alluvial fans on Earth with a total surface area exceeding $54,000 \mathrm{~km}^{2}$ (Silva and Abdon, 1998). The Taquari fan lies on the eastern part of the Pantanal and the Nhecolândia region lies on the southern half of the fan (about $28,000 \mathrm{~km}^{2}$ ). It corresponds to one of the sub-regions of the Pantanal delimited by the Taquari river in the north and northwest, the Paraguay river in the west, the Negro river in the south, and by a highland plateau in the east, called Serra de Maracajú.

The seasonal floods of Nhecolândia floodplain occur in three ways: (1) the overflow of the Taquari river across its natural levees, (2) a backwater effect caused by the flooding of the Paraguay and Negro rivers that can locally and temporarily reverse the flow of some tributaries (Hamilton et al., 1998), and (3) local rainfall on gentle slopes, which delay the drainage into the river (Hamilton, 1999). The local hydrologic regime is also very complex, and the several ground water flows connecting the many lakes of the Nhecolândia are not yet understood. The saline lakes almost never dry up, although their water level is always lower than that of the nearest freshwater lakes (Sakamoto, 1997). During the dry season, the lakes cover about $30 \%$ of the area. Among all the lakes of Nhecolândia, Morrison et al. (2000) identified 499 salty lakes, which make up about $1 \%$ of the total surface area.

The landscape is composed of special features indicated by distinctive regional terms, which will be used throughout the article:

- The "lagoas" are temporary or permanent freshwater lakes with variable forms and dimensions. They can reach approximately two metres in depth.

- The "salinas" are permanent salty lakes. They are generally 500 to $1000 \mathrm{~m}$ in diameter, 2 to $3 \mathrm{~m}$ deep (during the dry season), and most commonly bounded by a strip of dry land or "cordilheira."

- The "cordilheiras" are narrow (200-300 m wide) and elongated sand hills (2 to $5 \mathrm{~m}$ high) covered by savannah vegetation (cerrado).

- The "campos" are grassy meadows. 
Hot rainy summers from November to March and dry winters from April to October characterize the climate. The average annual precipitation is about $1000 \mathrm{~mm}$ and the annual evapotranspiration about $1400 \mathrm{~mm}$. Present-day geomorphological features are considered as relicts of a complex history of paleoclimatic and paleogeographic changes (Assine, 2005). Soils are developed on thick sequences of Quaternary sediments. The bedrock, which is several hundred metres deep (Ussami et al., 1999), cannot directly influence the local variability in the water geochemistry.

The study has been carried out in the Nhumirím farm of the EMBRAPA (Brazilian Institute for Agricultural Research) representative of the Nhecolândia region. The fieldwork was concentrated around the "Meio" saline lake located at $18^{\circ} 58^{\prime} \mathrm{S}$ and $56^{\circ} 38^{\prime} \mathrm{W}$ (Fig. 3).

\section{Material and method}

\subsection{Soil cover}

The soil morphology was studied in detail along radial transects established between the salina and the lagoa, and towards the adjacent upland (Fig. 3). Soil horizons were identified, described and sampled for laboratory analysis from 47 auger holes and 4 soil pits, which were usually excavated at lateral transitions between horizons.

In some sectors of the transects that showed specific lateral transitions, the soil morphology was compared to the soil electrical conductivity measured from the topsoil using an electromagnetic conductimeter (EM38, Geonics, Ltd, Ontario, Canada). This portable device is used to delineate changes in soil salinity, texture and water contents in the soil cover. This instrument measures apparent soil electrical conductivity $\left(\mathrm{EC}_{\mathrm{m}}\right)$ in milliSiemens per metre $\left(\mathrm{mS} \mathrm{m}^{-1}\right)$. The measurements were made in the vertical mode, i.e., about $75 \%$ of the signal is estimated to come from the top $1.8 \mathrm{~m}$ of the soil (McNeill, 1980).

Based on the above relationships, the distribution of specific soil features was surveyed by electromagnetic conductivity measurements using a regular $10 \mathrm{~m}-10 \mathrm{~m}$ grid around both salina and lagoa. The electromagnetic survey was carried out during the dry season of 2001 in the lagoa and during the severe drought of 2002 in the salina, when water was found only in the centre of the lake. In order to draw the map of electromagnetic conductivity by kriging, and to verify if the density of measurements was sufficient to represent the spatial distribution, the $\mathrm{EC}_{\mathrm{m}}$ data underwent a geostatistical treatment. A chi-squared test revealed that the data show a normal distribution. Therefore, the calculation was performed directly on the bulk data without transformation (Dowd, 1982). The kriged map was built from a model fitted on the sample variogram using the least squares method. 
The hydraulic conductivity of each horizon was measured in the excavated pits by means of Decagon ${ }^{\circledR}$ disk infiltrometer (Zhang, 1997).

\subsection{Water table monitoring}

A set of 15 piezometers were installed along the transect during the dry season of October 1998. The piezometers are made of two PVC pipes. The external 7-cm-diam pipes were installed in holes drilled by hand auger inside which another pipe of $4.5 \mathrm{~cm}$ diameter was inserted and the gap between the pipes was filled with flint gravels. The topographic heights of the landscape and piezometers were determined by theodolite, and the depth of the groundwater table was measured manually every 10 days for 6 years from October 1998 to October 2004. The piezometers are located in different landscape units as presented in Fig. 4. Rainfall was measured at the meteorological station of EMBRAPA located at the Nhumirím farm at $3 \mathrm{~km}$ from our study site.

\subsection{Water table chemistry}

Watertable samplers consisting of pierced polyethylene containers were installed in the watertable through augered holes. The $120 \mathrm{ml}$ containers were wrapped with a synthetic tissue to prevent clogging by soil particles. A capillary tube (1 $\mathrm{mm}$ diam), inserted into the sampler, reaches the soil surface, allowing samples to be collected. After installing the samplers, the holes were filled with the initial material preserving the order of the different layers up to the soil surface. The sampling device prevents contact between the water table and the atmosphere and thus preserves the redox conditions of the watertable with the sample.

Sets of water samples were collected seven times in October 2000, April and November 2001, October 2002, July 2003, May and October 2004. In the piezometers, samples were taken after removing about 1 liter of solution, which is approximately the quantity of water stored in the pipe of the piezometer. In the water table samplers, samples were taken by gentle pumping with hand vacuum pump in order to prevent drastic changes in the redox conditions. Redox (Eh) was immediately measured ( $\sim 5$ seconds) using a platinum probe. Temperature (T), electrical conductivity (EC) and $\mathrm{pH}$ were determined in the field. Then the samples were filtered with a $0.2 \mu \mathrm{m}$ cellulose-acetate membrane syringe filter and collected in polyethylene containers previously acid-washed in a clean room. Samples collected for analysis of cations and trace elements were acidified using ultrapure $\mathrm{HNO}_{3}$. Samples for anion and dissolved organic carbon (DOC) analysis were not acidified. All the samples were 
collected in duplicate. Eh was also measured in the sediment at different places of the lagoa (25 measurements) and salina (15 measurements).

\subsection{Laboratory work}

Soil samples: The cation-exchange capacity (CEC) was measured by the $1 \mathrm{M}$ $\mathrm{NH}_{4} \mathrm{OAcetate}$ method at $\mathrm{pH} 7$ (Page et al., 1982). The exchangeable cations $\mathrm{Ca}^{2+}, \mathrm{Mg}^{2+}, \mathrm{Na}^{+}$ and $\mathrm{K}^{+}$(equivalent fractions) were extracted with $1 \mathrm{M} \mathrm{NH}_{4} \mathrm{Cl}$ and quantified by atomic absorption spectroscopy. The $<2 \mu \mathrm{m}$ clay fraction was separated by sedimentation after destruction of the organic matter with $\mathrm{NaOCl}$ at $\mathrm{pH} 9.5$ (Anderson, 1963). Oriented specimens were analysed by five different treatments: ethylene glycol solvation, $\mathrm{Mg}$ saturation, $\mathrm{K}$ saturation and heating of the K-saturated clay at 350 and $550{ }^{\circ} \mathrm{C}$ (Jackson, 1979) using a $\mathrm{CuK} \alpha$ radiation diffractometer with a graphite crystal monochromator. Analyses were run with a step size of $0.02^{\circ} 2 \theta$ and a count time of $1.0 \mathrm{~s}$ per step. Bulk samples were examined using a SEM. Analysis of $\mathrm{Si}, \mathrm{Al}, \mathrm{Fe}, \mathrm{Ca}, \mathrm{Mg}, \mathrm{Na}$ and $\mathrm{K}$ were performed on 5-mm compacted clay patches $(<2 \mu \mathrm{m}$ fraction) using an electronic microprobe fitted with wavelength-dispersive spectrometers. The clay fraction was analysed using a TEM with electron diffraction (ED) and energy dispersive x-ray analysis (EDXRA) capabilities. Carbonate nodules were sampled at 5 different places along the transect $\mathrm{T} 1$. The nodules were crushed in an agate mortar and chemical analyses (ICP-AES and ICPMS) were carried out on the powder after fusion in platinum bombs using $\mathrm{LiBO}_{4}$.

Water samples: Total alkalinity was determined by acid titration with $\mathrm{HCl}$ (Gran, 1952). Major elements were analysed by ion chromatography for anions $\left(\mathrm{F}^{-}, \mathrm{Cl}^{-}, \mathrm{Br}^{-}, \mathrm{NO}_{3}{ }^{-}, \mathrm{SO}_{4}{ }^{2-}\right.$,

$\mathrm{PO}_{4}{ }^{3-}$ ), atomic adsorption spectroscopy for cations in 2000 and 2001-samples and ICPMS for cations in 2002, 2003 and 2004-samples $\left(\mathrm{K}^{+}, \mathrm{Na}^{+}, \mathrm{Ca}^{2+}, \mathrm{Mg}^{2+}\right)$. Si, minor and trace elements were determined by ICP-MS. Analysis were interspersed and checked with standard reference material. Accuracy for most of the analysis of the major elements were shown to be below $2 \%$ without dilution and within $10 \%$ for analysis carried out after the highest dilution (500 times). Dissolved organic carbon (DOC) was analysed by combustion.

\subsection{Treatments for chemical data}


A principal component analysis based on the correlation matrix was performed on $\mathrm{pH}$, EC, major, minor and trace elements, and DOC in order to identify and quantify the main processes responsible for the variability in water quality.

In order to identify the sources and sinks of each element along the concentration process, the data are presented in concentration diagrams built using conservative tracer to estimate the concentration factor. Chloride is usually a conservative tracer and will only be removed from solution by precipitation as halite, whereas sodium is not truly conservative as it can be removed from solution by interaction with clay minerals or by precipitation (halite or Na-carbonates). However, in this study, $\mathrm{Na}^{+}$concentrations are higher, positively correlated with $\mathrm{Cl}^{-}$, and the use of $\mathrm{Na}^{+}$revealed the same trends but less scattered, without affecting the outcome of the investigation. Therefore, the concentration diagrams were built using $\mathrm{Na}^{+}$as a conservative tracer. If a Na-salt precipitation occurs then the concentration factor will be underestimated and this hypothesis needs to be verified in the case of highly saline waters.

The ionic speciation, activity, and the saturation with respect to minerals were calculated using two databases, PHREEQC and AQUA (Parkhurst, 1995; Valles et al. 1996) and both databases yielded very similar results. These two models are particularly suitable for alkaline environments although some imprecision has to be expected with respect to the saturation of $\mathrm{Na}$-carbonates salts. In the concentration diagrams, the dotted line denotes the simulation of a concentration by evaporation. For the modelling, the partial pressure of $\mathrm{CO}_{2}$ is calculated from the field-pH and from alkalinity data, while $\mathrm{O}_{2}$ fugacity is calculated from field $\mathrm{pH}$, $\mathrm{Eh}$ and T.

\section{Results}

\subsection{Soil cover}

Along T1 (Fig. 4), the soil is mostly composed of pale brown (10 YR 6/3) structureless (single grain) sandy material (referred as horizon 1 on Fig. 4), overlying an organic greyish brown (10 YR 4/2) massive, sandy material (horizon 2). Below, there is a light brownish grey (2.5Y 6/2), single grain, sandy horizon, with abundant blackish organic volumes and calcareous nodules (horizon 3). Subjacent to these layers, there is a massive, sodic and alkaline ( $\mathrm{pH}=9.5$ to 10.5$)$ greyish $(2.5 \mathrm{Y} \mathrm{5/1})$ loamy sand material (horizon 4). Further down, the texture changes to sandy loam where the colour turns green $(5 \mathrm{Y} \mathrm{5/2})$ and the material is indurate (horizon $5, \mathrm{pH}>10.5$ ). Towards the salina, a lateral differentiation is 
observed in the subsurface with the presence of a dark grey (10 YR 4/1) prismatic loamy sand material (horizon 6).

The contact between the sandy horizon (1,2 or 3) and the top of the sandy loam horizons (4 and 5) is undulating and occurs at $6 \mathrm{~m}$ depth from the top soil in the cordilheira and at 0.2 $\mathrm{m}$ depth close to the saline lake. Among the several heights in the undulation of the sandy loam horizons, the highest is between piezometer P2 and P3 and at a distance of about $40 \mathrm{~m}$ from the average shore location of the salina. Observations carried out along the sequences $\mathrm{T} 2$, T3 and T4 confirm the presence of the same type of rise in the sandy loam layers and they also reach almost the same topographic level. The rise is therefore interpreted to be continuous in the cordilheira all around the salina and will henceforth be referred to as the outer ring. Another similar rise in the sandy loam green layer was detected in the cordilheira located in the south of the lagoa but auger investigations revealed that it is discontinuous around P15 (Fig. 4). The transition from the sandy horizon 1, 2 or 3 to the sandy loam horizon 4 or 5 is usually abrupt, but appears more progressive and rust-coloured at certain specific places such as near the water-sampler G6, below the lagoa and in the southern cordilheira (horizon 7). The rust coloured transition is sandy with remnants of grey and green sandy loam volumes. It has a low $\mathrm{pH}$, of about 5 close to the lagoa, and reaches values close to 3.5 at G6.

The $\mathrm{Na}$ and $\mathrm{K}$ equivalent fractions increase with the increase in soil $\mathrm{pH}$ to reach very high values of about $50 \%$ and $35 \%$ in horizons 4 and 5, respectively. The clay $(<2 \mathrm{~mm})$ fraction consists largely of kaolinite and Fe-illite in both horizons 4 and 5, but horizon 5 is indurate with a cement of amorphous silica. TEM analysis with EDXRA and ED revealed mainly amorphous material enriched in $\mathrm{Si}$ and a well crystallized low charge mica, which was consistent with both X-ray diffraction and SEM results (Fig. 5). The analysis of the clay patches of horizons 4 and 5 revealed the following composition: $\mathrm{Si}$ (60 to 70\%), $\mathrm{Al}$ (15 to $25 \%), \mathrm{K}(6$ to $9 \%), \mathrm{Fe}$ (4 to $7 \%), \mathrm{Mg}(2$ to $3 \%$ ) and $\mathrm{Ca}(1$ to $6 \%$ ). The clay fraction in horizon 6 consists of saponite- and stevensite- type smectite with very low Al content and contains up to $15 \%$ of $\mathrm{Mg}$. More details are given by Furquim (2007). The cationic composition of the calcareous nodules consist of $\mathrm{Ca}$ (80 to $84 \%$ ), $\mathrm{Mg}$ (5 to $7 \%$ ), $\mathrm{Ba}$ (1 to $13 \%) \mathrm{Ti}(0.4$ to $4 \%)$ and $\mathrm{Sr}(0.4$ to $0.5 \%)$. A trona crust is observed on the shoreline of the salina due to the evaporation from the capillary zone.

Around the lagoa the electrical conductivity values $\left(\mathrm{EC}_{\mathrm{m}}\right)$ range from 0 to $80 \mathrm{mS} \mathrm{m}^{-1}$, with an average value of $12.8 \mathrm{mS} \mathrm{m}^{-1}$ and a standard deviation of $10.8 \mathrm{mS} \mathrm{m}^{-1}$, whereas around the salina $\mathrm{EC}_{\mathrm{m}}$ values range from 15 to $440 \mathrm{mS} \mathrm{m}^{-1}$, with an average value of $169 \mathrm{mS}$ 
$\mathrm{m}^{-1}$, and a standard deviation of $63 \mathrm{mS} \mathrm{m}^{-1}$. The experimental variogram (Fig. 6) shows a range of $20 \mathrm{~m}$ around the salina and $70 \mathrm{~m}$ around the lagoa without nugget effect, which indicates that the density of measurements $(10 \mathrm{~m})$ was enough to assess the spatial distribution of the soil electromagnetic conductivity at short distance. The variograms are best fitted by exponential models with the following characteristics: scale $=3300\left(\mathrm{mS} \mathrm{m}^{-1}\right)^{2}$, range $=17 \mathrm{~m}$, nugget $=0$ for the salina, and scale $=145\left(\mathrm{mS} \mathrm{m}^{-1}\right)^{2}$, ranges $=70 \mathrm{~m}$, nuggets $=$ 0 for the lagoa respectively.

The kriged maps of electromagnetic conductivity measurements of both lagoa and salina, presented in Fig. 6, confirm the heterogeneity of the studied sites in terms of electrical conductivity in the soil cover. Mainly two circular zones with high $\mathrm{EC}_{\mathrm{m}}$ values are detected around the salina. The outer one has the highest $\mathrm{EC}_{\mathrm{m}}$ values and is continuous around the lake and located at about $60 \mathrm{~m}$ from the shore. Observations carried out with auger holes revealed that these high values are due to the presence of highly saline water (electrical conductivity of about $30 \mathrm{mS} \mathrm{cm}^{-1}$ ) at about $0.5 \mathrm{~m}$ depth. This water is located in a circular depression formed by the undulation of the top of the horizon 5 . The inner zone with high values is observed at about 20 to $50 \mathrm{~m}$ from the shore, although of less contrast than the first one. Auger observations revealed that it is due to a rise of horizon 5 at about 0.3 to $0.5 \mathrm{~m}$ from the topsoil. It will later be referred as inner ring. Around the freshwater lagoa, the highest $\mathrm{EC}_{\mathrm{m}}$ values are distributed at the southeastern and southern part in a crescent-shape, which corresponds to the occurrence of horizon 4 and 5. Auger observations indicated that horizons 4 and 5 also occur below the lagoa but are discontinuously distributed as suggested on the map on Fig. 6. These horizons were not detected in the north of the lagoa, where low $\mathrm{EC}_{\mathrm{m}}$ values are recorded.

The hydraulic conductivity in the sandy horizon 1 is about $1.710^{-2} \mathrm{~cm} / \mathrm{s}$ and is lower in horizons 4 and 5 by factors of 400 and 1000, respectively.

\subsection{Watertable}

The variation of the water table in the year from 1998 to 2002 is shown in Fig. 7. October is considered the beginning of the rainy season. The annual rainfall for the period 1998-1999, 1999-2000, 2000-2001 and 2001-2002 was respectively 896 mm, 1340 mm, 1140 $\mathrm{mm}$ and $1013 \mathrm{~mm}$. Three groups of piezometers can be distinguished during this 4-yearperiod according to the water level fluctuations. The first group is consists of P10, P11, P14 and P15; i.e., the piezometers close to the lagoa. The water level in these piezometers is very similar throughout the period and shows a rapid increase after rain events. The second group 
consists of P9, P7, P5 and P3, with a water level that is less variable and changes that are more continuous throughout the year. After the strong rainy events, the increase in the water level for the second group is delayed by about 10 days compared to the first group. P7 and P9 show a water level usually at about $0.3 \mathrm{~m}$ below that of P3 and P5. Finally, the main lateral change in the watertable level along the transect occurs between P3 and P2, which are only 30 meters apart. Throughout the year, P2, which is close to the salina, is almost always lower than P3 by about $0.75 \mathrm{~m}$. However, immediately after the storm events at the beginning of the rainy season, P2 can fleetingly exceed P3 (Fig. 7). During the rainy season, the level of P2 is the same as that of the salina, but exceeds it by 0.3 to $0.5 \mathrm{~m}$ during the dry season.

\subsection{Water chemistry}

The summarized statistics for major elements in water are presented in Table 1. Drastic changes are observed along transect $\mathrm{T} 1$ where the electrical conductivity of the water ranges from 0.015 to $70 \mathrm{mS} . \mathrm{cm}^{-1}$, $\mathrm{pH}$ from 3.7 to 10.5 and the ionic strength of the solutions varied from $0.7910^{-4} \mathrm{M}$ to $0.973 \mathrm{M}$. Among the major elements in the set of data, Na showed the largest standard deviation. The total dissolved ion concentration based on electrical conductivity varied by a factor of 498 in October 2000, 1905 in April 2001, 720 in November 2001, 4646 in October 2002, 1018 in July 2003, 1980 in May 2004 and 457 in October 2004. However, according to the sodium content from all the sets of samples, the most mineralised sample was 27145 times more concentrated than the least mineralised one. The less saline solutions were of $\mathrm{Na}-\mathrm{K}-\mathrm{HCO}_{3}$ type, whereas the most saline ones were of $\mathrm{Na}-\mathrm{HCO}_{3}$ type. Sulphate contents were low, reaching only a maximum of $5.54 \mathrm{mM}$ and in particular for the set of data at P16 in April 2001.

Among the major components, the correlation matrix shows close relationships between $\mathrm{EC}, \mathrm{Cl}^{-}, \mathrm{Br}^{-}, \mathrm{Na}^{+}$, alkalinity, $\mathrm{F}^{-}$and $\mathrm{K}^{+}$(Table 2). The examination of the singular values revealed that the two axes of the first factorial plan of the PCA carried out on major and minor elements accounted for 57\% and $14 \%$ in the variance of the data set (Table 3). Along the first axis saline waters around the salina were in opposition to freshwaters from the lagoa and cordilheira. The second axis opposed high $\mathrm{Ca}^{2+}$ and $\mathrm{Mg}^{2+}$ samples with the rest of the sampling. The third axis of the PCA accounted for $9 \%$ of the variance and differentiated samples with low $\mathrm{pH}$ and low sulphate contents and opposed the samples collected at G6 with the rest of the sampling. Lastly, both the fourth and fifth axis accounted for 5\% and 3\% of the variance and moderately opposed $\mathrm{Ca}^{2+}$ and $\mathrm{Mg}^{2+}$ and $\mathrm{Ca}^{2+}$ and $\mathrm{SO}_{4}{ }^{2-}$, respectively. 
However, due to the low weight of these two axis, they could also be due to a background noise induced by the analytical uncertainty.

The calculations indicated that the less mineralised solutions are under-saturated with respect to calcite, whereas the others are at equilibrium or slightly over-saturated. The most concentrated solution remains under saturated, but close to equilibrium, with respect to the sodium carbonates, although they were usually observed around the salina at the end of the dry season. These conditions of salinity reached the limitations of the model used. All the samples are under saturated with respect to salts like gypsum $\left(\mathrm{CaSO}_{4}, 2 \mathrm{H}_{2} \mathrm{O}\right)$ and halite $(\mathrm{NaCl})$. Except for the acidic samples taken at G6, the most saline samples reached saturation with respect to $\mathrm{Mg}$-silicates (stevensite, sepiolite, or Mg-smectite) and also to the $\mathrm{Na}$-silicates (kanemite, magadiite and kenyaite), which are typical silicates of alkaline environments (Fig. 8). The saturation for fluorite $\left(\mathrm{CaF}_{2}\right)$ is reached for the most saline samples in 2003.

Among the major elements, only $\mathrm{Cl}^{-}$and $\mathrm{Br}^{-}$show evolutions proportional to sodium (Fig. 9). Carbonate alkalinity is in agreement with simulation that takes into account the precipitation of calcite. The plots of calcium and magnesium are scattered, but their evolution is roughly in agreement with the simulation of evaporation taking into account the formation of calcite and $\mathrm{Mg}$-silicates (stevensite). For sodium above $10 \mathrm{mM}, \mathrm{K}^{+}$increased in proportion to $\mathrm{Na}^{+}$but for $\mathrm{Na}^{+}$ranging from 0.1 to $10 \mathrm{mM}, \mathrm{K}^{+}$looked controlled and increased less steadily. A similar shape is observed for the scattered plots of $\mathrm{F}^{-}$, and $\mathrm{SO}_{4}{ }^{2-}$. Total silica contents are close to $1 \mathrm{mM}$ for sodium molalities ranging from 0.07 to $7.5 \mathrm{mM}$ and then increase in the most mineralized samples (Fig. 10).

Among the salts involving minor elements, witherite $\left(\mathrm{BaCO}_{3}\right)$ and strontianite $\left(\mathrm{SrCO}_{3}\right)$ reached saturation (Fig. 11) but all samples remained under-saturated with respect to barite $\left(\mathrm{BaSO}_{4}\right)$ and celestite $\left(\mathrm{SrSO}_{4}\right)$. Both $\mathrm{Ba}^{2+}$ and $\mathrm{Sr}^{2+}$ show an evolution very similar to that of $\mathrm{Ca}$ on the concentration diagram. Although many minor elements are well correlated with $\mathrm{Na}$ contents, only 4 of them (As, Mo, V, U) show an evolution close to the unit slope (Fig. 12) on the concentration diagram and are clearly associated to the first axis of the PCA.

Water samples collected around the lagoa are enriched in several major $\left(\mathrm{K}^{+}, \mathrm{SO}_{4}{ }^{2-}, \mathrm{F}^{-}\right)$ and minor elements (V, Mo, Li, Ti, Ni, Zn, Ga, U, Th, Al, Pb), in relation to the $\mathrm{Na}$ enrichment line. The samples collected from G6 have a very acidic chemical profile and were not drawn on the plot of alkalinity (Fig. 9), because their negative alkalinity was incompatible with the logarithmic scale used for the axis. However, in relation to $\mathrm{Na}^{+}$values, samples from G6 showed high $\mathrm{Cl}^{-}$and $\mathrm{Br}^{-}$values, and low $\mathrm{K}^{+}$and $\mathrm{SO}_{4}{ }^{2-}$ values compared to the rest of the samplings. 
Eh-pH conditions: Along the transect, tremendous contrasts exist in the distribution of $\mathrm{pH}$ and redox and they remained almost stable during the years (2000 to 2004) regardless of the season. The $\mathrm{pH} /$ redox values ranged from $6.5 /+250 \mathrm{mV}$ to $5.5 /+400 \mathrm{mV}$ around and in the lagoa and $8.5 /+50 \mathrm{mV}$ to $7.5 /+250 \mathrm{mV}$ in the cordilheira. On the shore around the salina, the $\mathrm{pH}$ and redox measurements ranged usually from $9.75 /-100 \mathrm{mV}$ to $8.5 /+50 \mathrm{mV}$, however redox values can reach higher values (up to $+250 \mathrm{mV}$ ) after rainfall. The $\mathrm{pH}$ and redox were about $9.8 /+50 \mathrm{mV}$ in the salina but went to $7.5 /-200 \mathrm{mV}$ to $8.5 /-350 \mathrm{mV}$ in the sediments of the salina. Every year, the highest redox value was measured in the acidic water at G6 where it ranged from +400 to $+500 \mathrm{mV}$ with $\mathrm{pH}$ values between 3 and 4 .

Large variations are observed in DOC values ranging from 5 to $12 \mathrm{ppm}$ in the cordilheira, 20 to $30 \mathrm{ppm}$ in the lagoa, and up to $450 \mathrm{ppm}$ in the salina and surrounding piezometers.

\section{Discussion}

\subsection{Soil cover and water flow}

The water table fluctuates in sandy material above the sandy loam horizons 4 and 5 . The soil morphology around the salina, including the different rises of the green and grey layers (horizons 4 and 5), is in every respect similar to that described in other areas of the Nhecolândia by Sakamoto (1997) and hence appears as representative of the region. Although the clay proportion is low in horizons 4 and 5, and therefore suitable for permeability, the presence of high sodium equivalent fraction $\mathrm{E}_{\mathrm{Na}}$ and the cementation by silica drastically decreases the water infiltration rate. Thus, the contact between horizon 1, 2 or 3 and 4 or 5 governs the water flow. More specifically, the rise of horizon 4 and 5 between P2 and P3 behaves as a 'threshold' controlling the flow of water between the lagoa and the salina (Fig. 13). At the beginning of the wet season, accumulation of rainfall in the Pantanal causes a rise in the water level and freshwater flows from the lagoa to the upland of the cordilheira. When it exceeds the morphological threshold between P2 and P3, it flows down toward the depression of the salina where it evaporates (Fig. 13a). Conversely, during the dry season, saline and fresh watertables are disconnected along the outer rise of the sandy loam horizon (outer ring between P2 and P3), which acts as a barrier against the backward propagation of saline water toward the fresh sandy aquifer. A backward propagation occurs temporarily during the rainy season with intensive rainfall, when the gradient is inverted 
between $\mathrm{P} 2$ and $\mathrm{P} 3$, but only if the level at P2 is higher than the morphological threshold (Fig. 7).

The above-described hydrological regime explains how salinas and lagoas subjected to the same amount of evaporation and rainfall have different dissolved ion concentrations. The salinas become isolated from the regional fresh groundwater-surface water system due to the presence of low permeability soil horizons. These limit the flux of fresh groundwater into the salinas, which would have otherwise diluted the water. The surface water in the salina becomes saline due to the influence of evaporation (Evaporation/Rainfall $=1.4$ ). $\mathrm{Na}^{+}$contents increase in the salina and the shore and so do most ion concentrations. In contrast, the lagoas continually have water cycled through them so the effect of evaporation is much less pronounced.

In addition to the very local hydrological regime, Figure 3 shows that lagoas appear to be connected to other surface water bodies in the region, which implies a much greater catchment for surface water inflows, whereas the salinas have only a limited surface water catchment. Given the relatively high rainfall of the region, overland flow of fresh water may also help to keep the lagoas fresh compared to the salinas. As a conclusion, the lagoa and salina have very different water balances, both with surface water and groundwater components.

The differential hydrological regime between saline and freshwater lakes shows that it is not necessary to resort to changes in environmental conditions, and particularly to an arid period during the Pleistocene (Ab'Saber, 1988), to explain presence of saline waters in some lakes of the Nhecolândia, which results from a present day evaporation.

The co-existence of both types of lakes, namely salinas and lagoas, occurs because the distribution of the soil cover induces a differential hydrological regime. We therefore have to focus on the environmental conditions that favour and preserve the specificity of the soil cover; i.e., the sandy loam horizons, and particularly the morphologic threshold.

\subsection{Geochemical processes}

The hydrogeochemical data provide insights into the genesis of saline water in the salina as a result of the different hydrological regime to that in the lagoa, and also the genesis of the low permeability soil horizons, which ultimately control the flow of surface water and solutes into the lakes. 
Although the water salinity varied each year according to the quantity of rainfall, the differences in the chemistry are roughly maintained all year long. The first axis of the Principal Component Analysis indicates the overall concentration of the solutions. Considering the number of chemical parameters (46) and the number of samples (140) involved in the calculation, the very high percentage of the variance explained $(57 \%)$ emphasises that evaporation is the main process responsible for the chemical variability along the transect. The second factor for variability is through the control of $\mathrm{Ca}$ and $\mathrm{Mg}$, which is also related to evaporation and associated precipitations. The third factor for variability is a very localised acidification process that mainly affected the samples located at G6, and secondarily at P10, P11, P14, G14 and G15. The very low pH value and negative alkalinity observed at G6 will be discussed below. As indicated by axis 2, the same precipitation could be responsible for the control of both $\mathrm{Ca}$ and $\mathrm{Mg}$, but the fourth axis of the PCA also suggests independent processes in control of these two elements. Finally, the fifth factor suggests a severe geochemical control of sulphates at G6. These five processes amount to about $90 \%$ of the variance and will be analysed below.

\subsubsection{Evaporation, concentration and associated precipitations}

Evaporation explains $\mathrm{Na}^{+}$and $\mathrm{Cl}^{-}$concentrations in the water. Calcite precipitation explains the alkalinity and calcium contents. $\mathrm{Ca}$, unlike carbonate alkalinity, is strongly affected by calcite precipitation. In the freshwaters, alkalinity is higher than calcium concentration. Thus when the solutions concentrate and calcite precipitates, calcium concentration decreases and the carbonate alkalinity increases, although less than the sodium because a part of alkalinity is taken up from the solution for calcite formation. The control of calcium is frequently strengthened by formation of fluorite in alkaline environments (Barbiero and Van Vliet Lanoë, 1998; Chernet et al., 2002). A sink of $\mathrm{F}^{-}$seems to be identified on the concentration diagram because the enrichment of $\mathrm{F}^{-}$is lower than for $\mathrm{Na}^{+}$in the less saline solutions (Fig. 9). Fluorite is the least soluble F-containing mineral that might be expected to form and limit $\mathrm{F}^{-}$concentrations in low temperature systems. However, although the saturation with respect to fluorite is reached for the most saline samples in 2003, the control of $\mathrm{F}^{-}$is occurring in the most dilute solutions with $\mathrm{Na}^{+}$concentration close to 0.2 $\mathrm{mM}$, and with an absolute under saturation for fluorite (with $\log (\mathrm{Q} / \mathrm{K})$ of about $-2 ; \mathrm{Q}$ denotes ionic activity product and $\mathrm{K}^{+}$denotes the solubility product). Therefore, the precipitation of $\mathrm{CaF}_{2}$ cannot be responsible for the control of $\mathrm{F}^{-}$observed in the solution for $\mathrm{Na}^{+}$above $0.2 \mathrm{mM}$. The shape of the $\mathrm{F}^{-}$scatter plot is rather attributed to an increase in $\mathrm{F}^{-}$ 
values for low $\mathrm{Na}^{+}$contents (i.e. samples collected around the lagoa) than a control of $\mathrm{F}^{-}$ during the concentration process.

Up to $7 \%$ of $\mathrm{Mg}$ is incorporated in the calcareous nodules, which explains part of the lost of $\mathrm{Mg}^{2+}$ from the solution. This common control of $\mathrm{Ca}^{2+}$ and $\mathrm{Mg}^{2+}$ as carbonates is related to the second axis of the PCA and explains 9\% of the variance of the system. Ba and Sr are also incorporated in the carbonate nodules where they reached values ranging from 0.4 to $5 \%$ and 0.15 to $0.3 \%$ respectively.

Besides in carbonate, $\mathrm{Mg}$ is also involved in the formation of $\mathrm{Mg}$-silicates precipitating from the concentrated solutions (Garrels and Mackenzie, 1967; Gac et al., 1977; Jones et al., 1977) and corroborated by the presence of trioctahedral saponite- and stevensite- type smectite around the salina. Moreover, the scattered plot for $\mathrm{Mg}^{2+}$ is roughly in agreement with Mg-evolution in the simulation of stevensite formation during evaporation (Fig. 9). The fourth axis of the PCA, opposing the variables $\mathrm{Ca}^{2+}$ and $\mathrm{Mg}^{2+}$, may relate to the formation of Mg-silicates.

The high silica contents observed in the most concentrated solution, i.e. solution with $\mathrm{pH}$ above 9 , is attributed to the dissociation of orthosilicic acid $\left(\mathrm{H}_{4} \mathrm{SiO}_{4}\right)$ into $\mathrm{H}_{3} \mathrm{SiO}_{4}{ }^{-}$.

The low enrichment of $\mathrm{K}^{+}$suggests a removal from the solution as it becomes more saline (Furquim et al., 2004). $\mathrm{K}^{+}$is adsorbed on the exchange complex as shown by the increase in $\mathrm{E}_{\mathrm{K}}$ equivalent fraction with increasing $\mathrm{pH}$ in horizon 4 and 5 . Moreover, figures 4 and 6 show that the green horizons 4 and 5, where a large proportion of Fe-illite is noted in the clay fraction, are clearly related to the presence and functioning of the saline lake, and cannot be attributed to a prior sedimentation. Formation of illite from smectite has already been described in African alkaline lakes (Singer \& Stoffers 1980; Jones \& Weir 1983), but in our study it appears unlikely, because the proportion of smectite in horizon 4 and 5 is almost zero. K-silicates were mentioned in many sodic-alkaline environments in association with sepiolite, saponite and stevensite (Buch and Rose, 1996). From X-ray, SEM and TEM observations, from the chemistry of the solution and the morphology of the soil cover, the formation of illite is postulated in this environment. The direct formation of K-silicates or crystallization of K-silicates from amorphous material has already been recorded in two similar alkaline environments, in the sediment beneath the trona-rich Searles Lake of California (Hay and Moiola, 1963) and beneath the trona pan of islands in the Okavango Delta (McCarthy et al., 1991; Ramberg and Wolski, 2008). Further investigation at the solution-mineral interface is currently carried out to verify this assumption. 
The increase in the $\mathrm{pH}$ value favours the dissolution of organic matter and consequently high DOC contents are found in the salina and surrounding piezometers. Because the increase in the $\mathrm{pH}$ value is due to the evaporation process, these high DOC contents are also directly related to high electrical conductivities. Moreover, the dissolved organic matter mainly consists in ionisable compounds due to the presence of a wide variety of oxygen containing functional groups. Usual $\mathrm{pKa}$ values for natural organic matter are determined by the two most abundant functional groups, 4.7 (carboxyl group) and 10 (phenol group). Consequently, at the observed $\mathrm{pH}$ values the dissolved organic compounds are mostly anionic and are also partly contributing to the high electrical conductivity (Mariot et al., 2007).

Trace element species in natural waters depend largely on the complexation and adsorption process and from physico-chemical conditions such as $\mathrm{pH}$, redox, dissolved solid contents, and anion concentrations because the main ligands are $\mathrm{OH}^{-}, \mathrm{HCO}_{3}{ }^{-}, \mathrm{CO}_{3}{ }^{2-}, \mathrm{SO}_{4}{ }^{2-}$, $\mathrm{Cl}^{-}$and $\mathrm{F}^{-}$. The calculation suggests that the Ag-chloride complexes $\left(\mathrm{AgCl}_{2}{ }^{-}, \mathrm{AgCl}_{3}{ }^{2-}\right)$ are the predominant forms of dissolved silver in the saline-alkaline environment, whereas metallic elements such as $\mathrm{Cu}, \mathrm{Pb}, \mathrm{Mn}$, are complexed with carbonate ions and form dicarbonate complexes. Zinc is mainly complexed with carbonate and secondarily forms hydroxocomplexes. Hydroxocomplexes are dominant aqueous species for $\mathrm{Be}, \mathrm{Bi}$ and $\mathrm{Nb}$. The geochemical context of high $\mathrm{pH}$ and alkaline water composition and low calcium contents, favours the concentration of Mo, As, $\mathrm{V}$ in the form of oxyanions that form complexes with sodium and have high solubility. These elements increased with most of the other dissolved species; hence competitive adsorption prevents their dissolved regulation by solid phase reaction. Moreover, the $\mathrm{pH}$-values increased above 8 favouring their desorption from $\mathrm{Fe}$ oxide or hydroxide and clay minerals (Goldberg, 2002). Therefore these elements increase in proportion to sodium, i.e., in proportion to the reduction of volume of water during evaporation. More information regarding the arsenic redox state was presented in another paper (Barbiero et al., 2007). Although the enrichment of selenium is lower than for $\mathrm{Na}^{+}$ possibly because of to Se biomethylation (Thompson-Eagle and Frankenberger, 1991), a good correlation exists between the two as indicated by the correlation matrix of the PCA (0.976). As a consequence, Se reachs high values $\left(200 \mu \mathrm{gl}^{-1}\right)$ clearly above the water quality recommendations (usually $5 \mu \mathrm{gl}^{-1}$ ).

\subsubsection{Specificity of acidic samples}

The production of acidity induced by the oxidation of sulphide minerals has to be considered to explain the acidic solutions sampled at G6 (Fig. 4 and 7). They are saline and 
always show $\mathrm{pH}$ values close to $3.5-4$, but they are also always strongly depleted in $\mathrm{SO}_{4}{ }^{2-}$ (100 times compared to the sodium enrichment line, Fig. 9) and slightly depleted in arsenic (3 times, Fig. 12). Therefore, the hypothesis of oxidation of pyrite or arsenopyrite to explain the low $\mathrm{pH}$ must be rejected. On the other hand, the solutions are enriched in $\mathrm{Cl}^{-}$(4 times) and it seems that the dynamic of $\mathrm{Cl}^{-}$is involved in the process responsible for low $\mathrm{pH}$ values. This point should therefore be the subject of a specific study.

\subsection{Dynamics of the soil cover}

At the beginning of the dry season, the high level of saline water fluctuates and, in the vegetated fringe of the cordilheira, the water loss by transpiration increases dissolved salt contents in the groundwater leading to the saturation with respect to calcite, amorphous silica, and clay minerals. Chemical precipitation of these components may build the sandy loam horizons 4 and 5 upward at the outer ring (Fig. 13b). During severe drought, the disconnection between fresh and saline water tables occurs early. Because the bottom of the saline water consists of impervious horizons 4 and 5 that are close to the surface, the volume of water is low and the saline water levels drop abruptly through evaporation (Fig. 13c). The groundwater emerges only in the centre of the salina where extreme evaporative concentration occurs, and calcite, $\mathrm{SiO}_{2}$ and clay minerals precipitate on the shore, generating the inner ring observed during the $\mathrm{EC}_{\mathrm{m}}$ geophysical survey. This inner ring also acts as a barrier disconnecting two saline watertables: one is outside the ring in the circular gutter and the other one is in the centre of the lake.

Soil horizons 4 and 5 with high $\mathrm{E}_{\mathrm{Na}}$ are on the shore and beneath both salina and lagoa. These soil horizons are in equilibrium with the saline alkaline environment of the salina but not with the freshwater environment of the lagoa. Moreover, the cementation of the sandy loam horizon 5 necessarily occurs in an alkaline environment that favours the dissociation of silica. Correspondingly, several morphological observations indicate the destruction of the sandy loam horizon 4 and 5 around and below the lagoa. They are: 1 - the rust-coloured sandy horizon 7 which appears as a transition between horizons 4 or 5 and horizon 1, and in which sandy loam remnants were detected; 2 - the crescent shaped and discontinuous distribution of horizons 4 and 5 around the lagoa that likely arise from a former continuous inner ring (Fig. 6), and that has been partially destroyed; 3 - the higher and second rise of horizon 5 observed in the southern cordilheira (Fig. 4), which can be compared to the continuous outer ring observed around the salina. Because they are discontinuous around the lagoa, horizon 4 and 5 are not anymore controlling the water flow. From these observations 
we interpret the lagoa as a former salina that is currently supplied by fresh water and hence desalinised. Such a transformation is likely to occur in the future in the here studied Meio saline lake, and for further study, it should be valuable to determine the implications for the ecosystems in this environment.

The destruction of sandy loam horizons has implications for the chemistry of lagoa water, detected mainly from $\mathrm{K}^{+}, \mathrm{F}^{-}, \mathrm{SO}_{4}{ }^{2-}$ and minor element scatter plots (Fig. 9 and 12). Fig. 14 shows the relation of a linear combination of the clay fraction and calcareous nodule compositions, to the enrichment in the chemistry of the lagoa water. A contribution of the clay fraction ten times higher than that of the calcareous nodules is considered. A unit slope linear relationship is expected if the dissolution of these two phases is responsible for the changes observed in the lagoa freshwater. This is the case for most of the chemical elements plotted (U, Ni, Th, Rb, Zr, Sc, Pb, Co, Sr, Ba, Ti, F, K, Al and Fe). This result attests to the contribution of these two phases, and roughly in this proportion $(10: 1)$, to the chemistry of the freshwater system at the local scale.

\section{Conclusions}

The Nhecolândia, in the Pantanal wetland in central Brazil, has a surprisingly large number of lakes, many of them with saline alkaline water. The origin of these lakes has been attributed to aeolian processes because many relict aeolian landforms are preserved in the landscape (Assine and Soares, 2004), or to alternation of wet and arid phases during the Pleistocene. In fact, the genesis of these lakes was not satisfactorily explained. A previous study, based on chemical considerations of major elements, showed that saline water could arise from freshwaters through a present-day concentration process at the regional scale of the whole Nhecolândia. The present study focuses on the soil cover, water and solute flows in the landscape to explain how wetlands subjected to the same climatic conditions can have such different chemical characteristics.

The study highlights an important interaction between the saline and freshwater lakes, which has implications for the functioning of the Pantanal ecosystem, involving dissolution and transfer of chemical elements and organic matter (Mariot et al., 2007). It confirms that the co-existence of saline and freshwater lakes is due to a differential hydrological regime, where the freshwater is directed towards the depressions of the saline lakes. The water is lost from the saline lake by evaporation and is offset by inflow from the freshwater system. The inflow is controlled by the morphology of the soil cover, and particularly by the presence of a 
morphological threshold consisting of green and grey sandy loam horizons, with high sodium equivalent fraction on the exchange complex and partially cemented by silica. This threshold is continuous and functional around the saline lake, where it is still forming, but discontinuous and non-functional around the freshwater lake, where it is disintegrating. The changes in the chemical composition from fresh to saline water, is due to Mg-calcite precipitation, Mg-silicates (saponite- and stevensite-type minerals), Fe-illite, and eventually trona for very concentrated solutions. $\mathrm{Ba}^{2+}$ and $\mathrm{Sr}^{2+}$ are controlled by co-precipitation with $\mathrm{Ca}^{2+}$ and $\mathrm{Mg}^{2+}$ in calcareous nodules.

Although the present study described the functioning of the lakes, the equilibrium between solid and liquid phases and the dynamic of the soil cover, many points remain unclear. Are these lakes still forming under the present hydro-climatic conditions of the Pantanal? Are saline lakes disappearing at the expense of freshwater lakes? This study highlight that the chemical profile of the water, depleted in $\mathrm{Ca}^{2+}$ and $\mathrm{Mg}^{2+}$ and evolving in an alkaline way under the influence of evaporation, is a first prerequisite for the functioning of these lakes, but the next research efforts should be focused on the hydrological, sedimentological and climatic conditions initiating and controlling their development.

\section{Acknowledgement}

This study has been realised in the framework of a CAPES-COFECUB cooperation (412/03) between France (University of Paris 7) and Brazil (University of Sao Paulo). The Authors are grateful to the EMBRAPA Pantanal and SEMA of South Mato-Grosso for field assistance. We thank Dr. Vasanthi Dass for editorial advice.

\section{References}

Ab'Saber, A.N., 1988. O Pantanal Mato Grossense e a teoria dos refúgios. Revista Brasileira de Geografia 50, 9-57.

Almeida, F.F.M., 1945. Geologia do sudoeste Matogrossense. DNPM/DGM, Boletim 116, 118.

Almeida, F.F.M., Lima, M.A., 1956. Excursion Guidebook 1. 18th International Congress of Geography, Rio de Janeiro, Brazil.

Anderson, J.U., 1963. An improved pretreatement for mineralogical analysis of samples containing organic matter. Clays and Clay Minerals 10, 380-388. 
Assine, M.L., Soares, P.C., 2004. Quaternary of the Pantanal, west-central Brazil. Quaternary International 114, 23-34.

Assine, M.L., 2005. River avulsions on the Taquari megafan, Pantanal wetland, Brazil. Geomorphology 70, 357-371.

Barbiero, L., Van Vliet Lanoe, B., 1998. The alkaline soils of the Niger valley. Origins, formation and present evolution. Geoderma 84, 323-343.

Barbiero, L., Queiroz Neto, J.P., Ciornei, G., Sakamoto, A.Y., Capellari, B., Fernandes, E., Valles, V., 2002. Geochemistry of water and ground water in the Nhecolândia, Pantanal of Mato Grosso, Brazil: variability and Associated processes. Wetlands 22, 528-540.

Barbiero, L., Furquim, S.C., Valles, V., Furian, S., Sakamoto, A., Rezende Filho, A.T., Fort, M., 2007. Natural arsenic in Groundwater and alkaline lakes at the upper Paraguay basin, Pantanal, Brazil. In Battacharya P., Mukherjee A.B., Loeppert R.H. (Ed.) Arsenic in Soil and Groundwater Environment: Biogeochemical interactions. Elsevier Book Series "Trace metals and other contaminants in the environment" (J.O. Nriagu, Serie Ed.).

Brum, P.A.R., Souza, J. C., 1985. Níveis de nutrientes minerais para gado em lagoas no Pantanal Sul Mato-Grossense. Pesquisa Agropecuária Brasileira 20, 1451-1454.

Buch, M.W., Rose, D., 1996. Mineralogy and geochemistry of the sediments of the Etosha pan region in northern Namibia: A reconstruction of the depositional environment. Journal of African Earth Science 22, 355-378.

Chernet, T., Travi, Y., Valles, V., 2001. Mechanism of degradation of the quality of natural water in the lakes region of the Ethiopian rift valley. Water Resources 35, 2819-2832.

Colinvaux, P.A., Oliveira P.E., Bush M.B., 2000. Amazonian and neotropical plant communities on glacial time-scales. The failure of the aridity and refuge hypotheses. Quaternary Science Reviews 19, 141-169.

Cunha, J., 1943. Análise química das águas. Cobre do Jauru : lagoas alcalinas do Pantanal. Boletim do Laboratório de Produção Mineira 6, 18-19.

Dowd, P.A., 1982. Lognormal kriging - the general case. Mathematical Geology 14, 475-499. Eiten, G., 1983. Classificação da vegetação do Brasil. CNPq/Coordonação editorial, Brasilia. Ferraz-Vicentini, K.R., Salgado-Labouriau, M.L., 1996. Palynological analysis of a palm swamp in central Brazil. Journal of South American Earth Sciences 9, 207-219.

Furquim, S.A.C., Graham, R.C., Queiroz Neto, J.P., Furian, S., Barbiero, L., 2004. Fe-illite neoformation in an alkaline environment, Pantanal wetland, Brazil. Proceeding of the Soil Science Society of America Annual Meeting. CD media, Seattle. 
Furquim, S.A.C., 2007. Formação de carbonatos e argilo-minerais em solos sódicos do Pantanal Sul-Mato-Grossense. PhD.Thesis, University of Sao Paulo, Brazil.

Garrels, R.M., Mackenzie F.T., 1967. Origin of the chemical composition of some springs and lakes, in Gould R.F. ed., Equilibrium concepts in natural water systems. Advances in Chemistry Series 67, 222-242.

Gac, J.Y., Droubi, A., Fritz, B., Tardy, Y., 1977. Geochemical behavior of Silica and magnesium during the evaporation of waters in Chad. Chemical Geology 19, 215-228.

Goldberg, S., 2002. Competitive adsorption of arsenate and arsenite on oxides and clay minerals. Soil Science Society of America Journal 66, 413-421.

Gottgens, J.F., Fortney, R.H., Meyer, J., Perry, J.E., Rood, B.E., 1998. The case of the Paraguay-Paraná waterway ("Hidrovia") and its impact on the Pantanal of Brazil: a summary report to the Society of Wetlands Scientists. Wetlands Bulletin, 12-18.

Gran, G., 1952. Determination of the equivalence point in potentiometric titrations. Acta Chemica Scandinavica 4, 559-577.

Hay, R.L., Moiola, R.J., 1963. Authigenic silicate minerals in Searles Lake, California. Sedimentology 2, 312-332.

Hamilton, S.K. 1999. Potential effects of a major navigation project (Paraguay-Parana hidrovia) on inundation in the Pantanal floodplains. Regulated Rivers: Research \& Management 15, 289-299.

Hamilton, S.K., Corrêa de Souza, O., Coutinho, M.E., 1998. Dynamic of floodplain inundation in the alluvial fan of the Taquari River (Pantanal, Brazil). Verhandlungen der Internationale Vereinigung für theoretische und angewandte Limnologie 26, 916-922.

Jackson, M.L., 1979. Soil Chemical Analysis-Advanced Course. (2nd ed.), Madison, WI.

Jones, B.F., Weir, A.H., 1983. Clay minerals of Lake Abert, an alkaline, saline lake. Clays and Clay Minerals 3, 161-172.

Jones, B.F., Eugster, H.P., Rettig, S.L., 1977. Hydrochemistry of Lake Magadi Basin, Kenya. Geochimica Cosmochimica Acta 41, 53-72.

Klammer, G., 1982. Die Palaeowuste des Pantanal von Mato Grosso und die pleistozane Klimageschichte des brasilianischen Randtropen. Zeitschrift für Geomorphologie 26, 393 416.

Ledru, M.P., Braga, M.P., Soubies, F., Fournier, M., Martin, L., Suguio, K., 1996. The last 50,000 years in the Neotropics (southern Brazil): evolution of vegetation and climate. Palaeogeography, Palaeoclimatology, Palaeoecology 123, 239-257. 
Mariot, M., Dudal, Y., Furian, S., Sakamoto, A.Y., Valles, V., Barbiero L., 2007. Dissolved organic matter fluorescence as a water flow tracer in the tropical wetland of Pantanal of Nhecolândia, Brazil. Science of the Total Environment 388, 183-196.

McCarthy, T.S., McIver, J.R., Verhagen, B.T., 1991. Groundwater evolution, chemical sedimentation and carbonate brine formation on an island in the Okavango Delta swamp, Botswana. Applied Geochemistry 6, 577-596.

McNeill, J.D., 1980. Survey Interpretation Techniques: EM38. Tech. Note TN-6, Geonics Pty, Ltd, Ontario, Canada

Morrison, R.I.G., Manore, M., Ross, R.K., Padovani, C.R., 2000. Identificação das lagoas salinas da região da Nhecolândia - Pantanal, através de técnicas de sensoriamento remoto. III Simpósio sobre Recursos Naturais e Sócio-econômicos do Pantanal, Corumbá-MS (Abstract), 88-89.

Mourão, G.M., Ishii, T.H., Campos Z.M.S. 1988. Alguns factores limnológicos relacionados com a íchtiofauna de baías e salinas do Pantanal da Nhecolândia, Mato Grosso do sul, Brasil. Acta Limnologica Brasiliensia 2, 181-198.

Page, A.L., Miller, R.H., Keeney, D.R., 1982. Methods of Soil Analysis: Part 2. Chemical and Microbiological Properties. (2nd ed.), American Society of Agronomy and Soil Science Society of America, Madison, WI.

Parkhurst, D.L., 1995. User's guide to PHREEQC-A computer program for speciation, reaction-path, advective-transport, and inverse geochemical calculations. Water-Resources Investigation Report 95-4227. U.S. Geological Survey, Lakewood CO.

Por, F.D., 1995. The Pantanal of Mato Grosso (Brazil). World's Largest Wetlands. Kluwer Academic Publisher, Monographiae Biologicae 73, Dordrecht/Boston/London.

Ramberg, L., Wolski, P., 2008. Growing islands and sinking solutes: processes maintaining the endorheic Okavango Delta as a freshwater system. Plant Ecology, in press.

Sakamoto, A.Y., 1997. Dinâmica hídrica em uma lagoa salina e seu entorno no Pantanal da Nhecolândia: contribuição ao estudo das relações entre o meio físico e a ocupação, Fazenda São Miguel do Firme, MS. Ph.D. Thesis. University Sao Paulo, Sao Paulo, Brazil. Silva, J.D., M.D. Abdon. 1998. Delimitation of the Brazilian Pantanal and its sub-regions. Pesquisa Agropecuaria Brasileira 33:1703-1711.

Singer, A., Stoffers, P., 1980. Clay mineral diagenesis in two East African lakes. Clay Minerals 15, 291-307.

Thompson-Eagle, E.T., Frankenberger Jr, W.T., 1991. Selenium biomethylation in an alkaline, saline environment. Water Research 25, 231-240. 
Tricart, J., 1982. El Pantanal : Un ejemplo del impacto de la Geomorphologia sobre el medio ambiente. Geografia 7, 37-50.

Ussami, N., Shiraiwa, S., Dominguez, J.M.L., 1999. Basement reactivation in a sub-Andean foreland flexural bulge: the Pantanal wetland, SW Brazil. Tectonics 18, 25-39.

Valles, V., Ribolzi, O., de Cockborne, A.M., Cornieles, M., 1996. Presentation de AQUA, logiciel de géochimie appliqué aux problèmes environnementaux. GRESSAP, 10 September 1996, ORSTOM, Montpellier.

Wilhelmy, M., 1958. Das Grosse Pantanal. Die Weltumschau 18, 555-559.

Zhang, R., 1997. Determination of soil sorptivity and hydraulic conductivity from the disk infiltrometer. Soil Science Society of America Journal 61, 1024-1030.

Fig. 1 - The Pantanal wetland, Brazil

Fig. 2 - The Taquari megafan and an aerial photograph showing the round lakes of the Nhecolândia.

Fig. 3 - Studied transects and distribution of the piezometers around the saline lake (salina) and an adjacent freshwater lake (lagoa).

Fig. 4 - Transect T1: piezometers, watertable samplers and distribution of the main horizons.

Fig. 5 - Transmission electron micrograph of sample from horizon 5 showing amorphous silica-rich phase with Fe-illite.

Fig. 6 - Experimental variogram, fitted model and electromagnetic conductivity $\left(\mathrm{EC}_{\mathrm{m}}\right)$ kriged map around the salina and lagoa.

Fig. 7 - Rainfall and water level fluctuations from October 1998 to November 2002 along T1. Upper graph: 3 groups of piezometers are discriminated. Lower graph: Water level fluctuations in P2 and P3 showing inflow from P3 to P2. Short periods of possible back propagation of saline water $(\mathrm{P} 2)$ into the fresh water aquifer $(\mathrm{P} 3)$ are highlighted in grey. 
Fig. 8 - Saturation diagrams for $\mathrm{Na}$ - and $\mathrm{Mg}$-silicates. Open circle are acidic samples from the water sampler G6.

Fig. 9 - Concentration diagram against $\mathrm{Na}$ for the major ions (in $\mathrm{mM}$ ). Open circle are acidic samples from $\mathrm{G} 6$. On the plot for $\mathrm{K}, \mathrm{F}$ and $\mathrm{SO}_{4}$, squares are samples collected in and around the lagoa. The dotted line is the simulation of evaporation activating the possible precipitation of calcite and stevensite.

Fig. 10 - The relation of $\mathrm{pH}$ to $\mathrm{Na}$ and the plot of abundances of $\mathrm{Si}$ against $\mathrm{Na}$ for groundwater and surface water. Open circle are acidic samples from G6.

Fig. 11 - Saturation diagram for strontianite $\left(\mathrm{SrCO}_{3}\right)$ and witherite $\left(\mathrm{BaCO}_{3}\right)$.

Fig. 12 - Plots of abundances of some minor elements against Na for waters collected along the transect T1. Samples from G6 (open circles) and around the lagoa (squares) are distinguished from the rest of the sampling (closed circles). Vertical bars are relative enrichments in the lagoa waters used for 'x' axis of Fig. 14.

Fig. 13 - Present day hydrological functioning of a saline lake in the Pantanal of Nhecolândia. (a) wet season: inflow from the fresh groundwater system to the saline lake; (b) dry season: disconnection between fresh and saline groundwater at the outer ring. Chemical precipitations occur at the shore of the lake, strengthening the rise of horizons 4 and 5 (Feillite, amorphous silica and calcite). Trioctahedral Mg-rich smectites (saponite and stevensite) precipitate at topsoil; (c) during severe drought or at the very end of the dry season: disconnection between the circular gutter and the centre of the saline lake. The above mentioned chemical precipitations occur also at the inner ring.

Fig. 14 - A linear combination of the composition of the clay fraction and calcareous nodules (10 Clay + Calc.) against the enrichment in the lagoa water (estimated from the concentration diagrams on Fig. 9 and 12). 


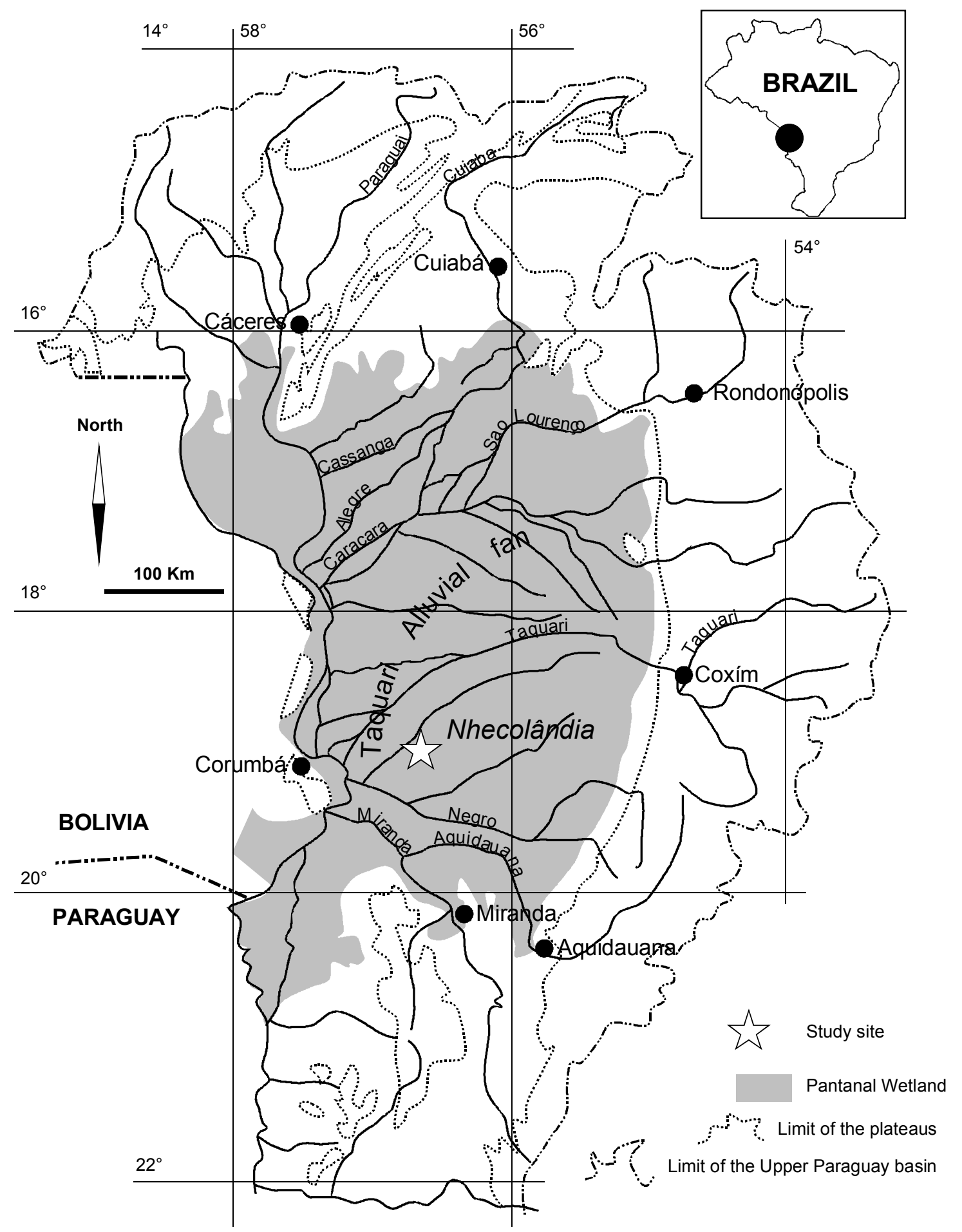

Fig. 1 - The Pantanal wetland, Brazil 


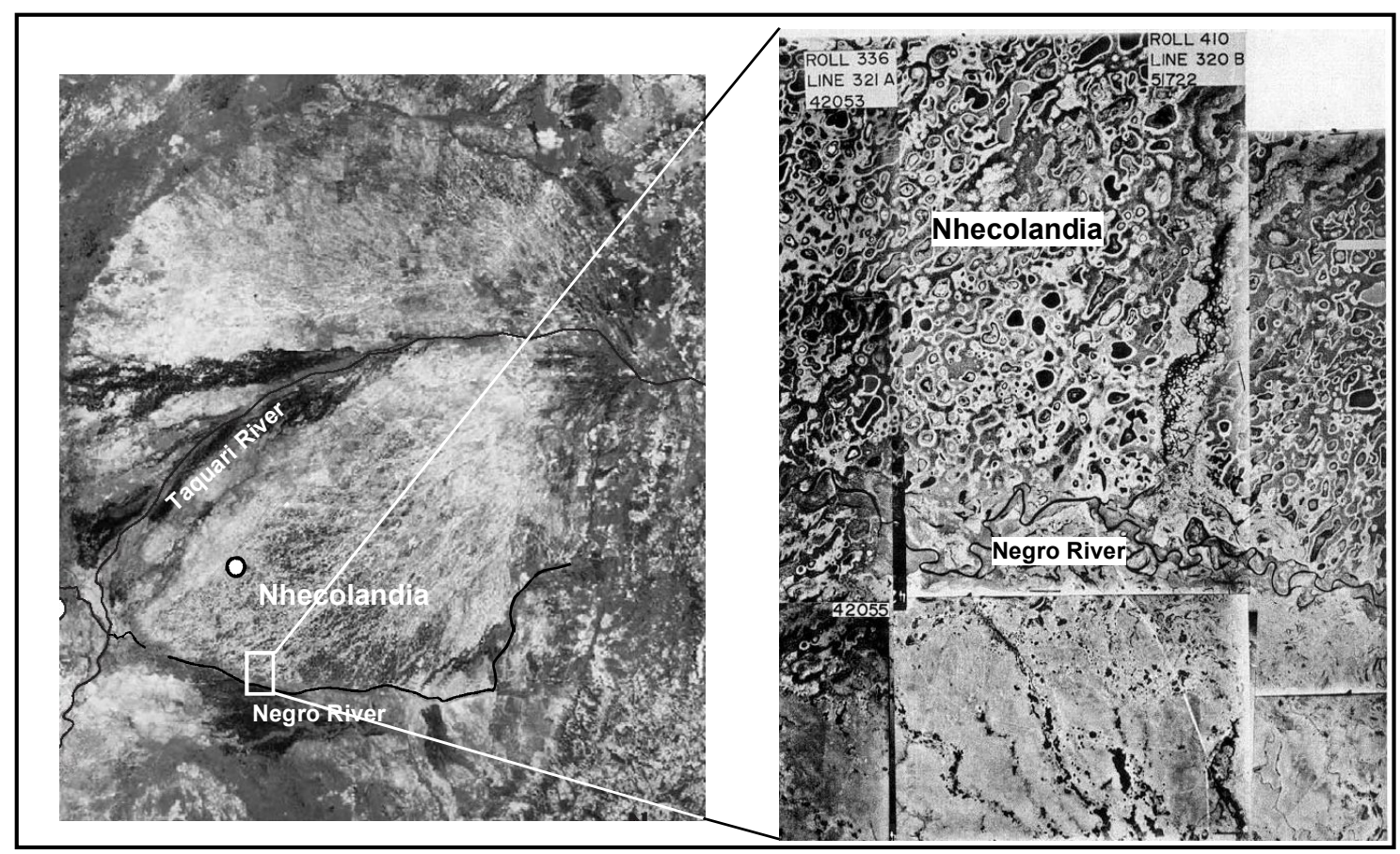

Fig. 2 - The Taquari megafan and an aerial picture showing the round lakes of the Nhecolândia. The circle represents the study site. 


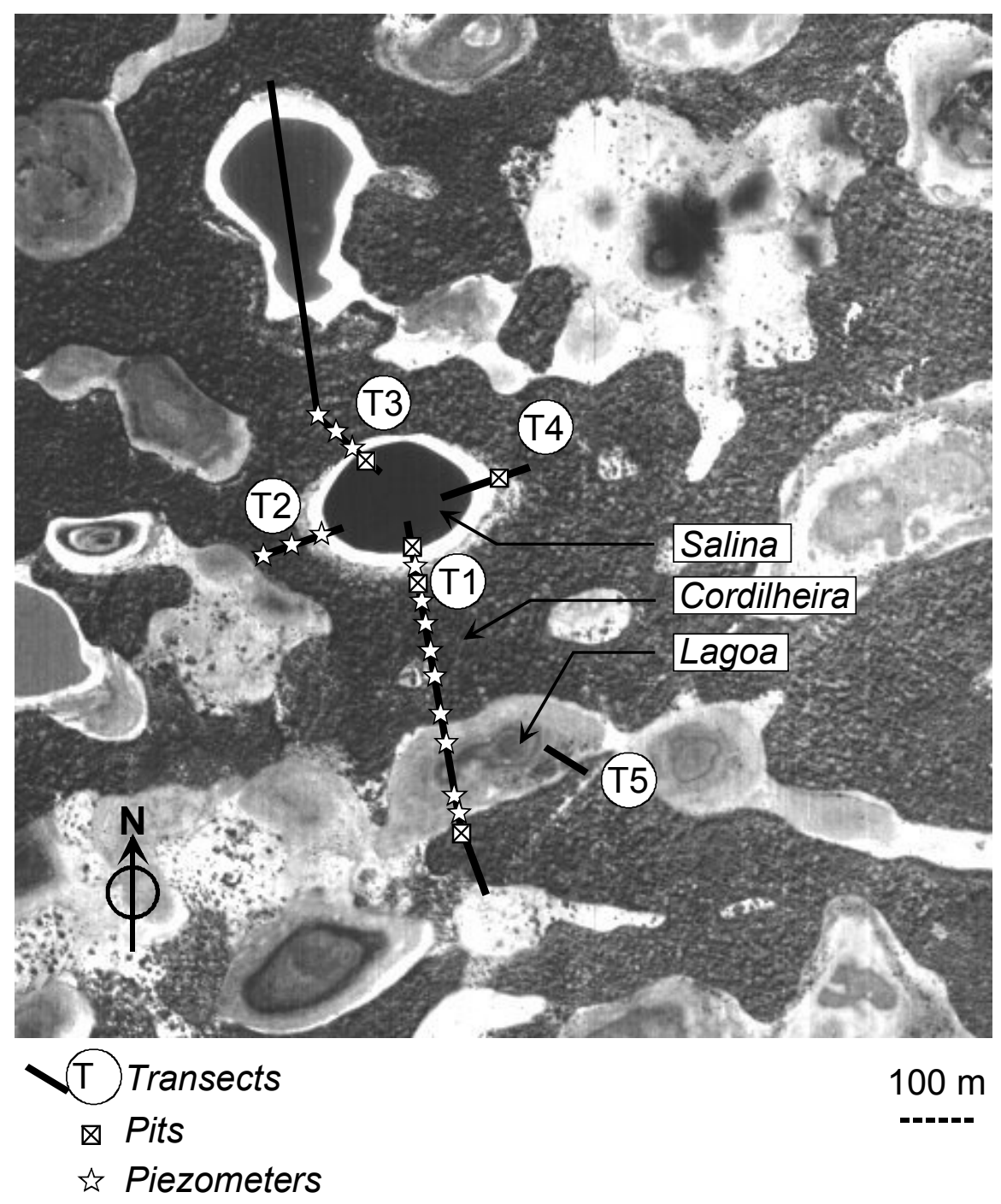

Fig. 3 - Studied transects and distribution of the piezometers around the saline lake (salina) and an adjacent freshwater lake (lagoa). 


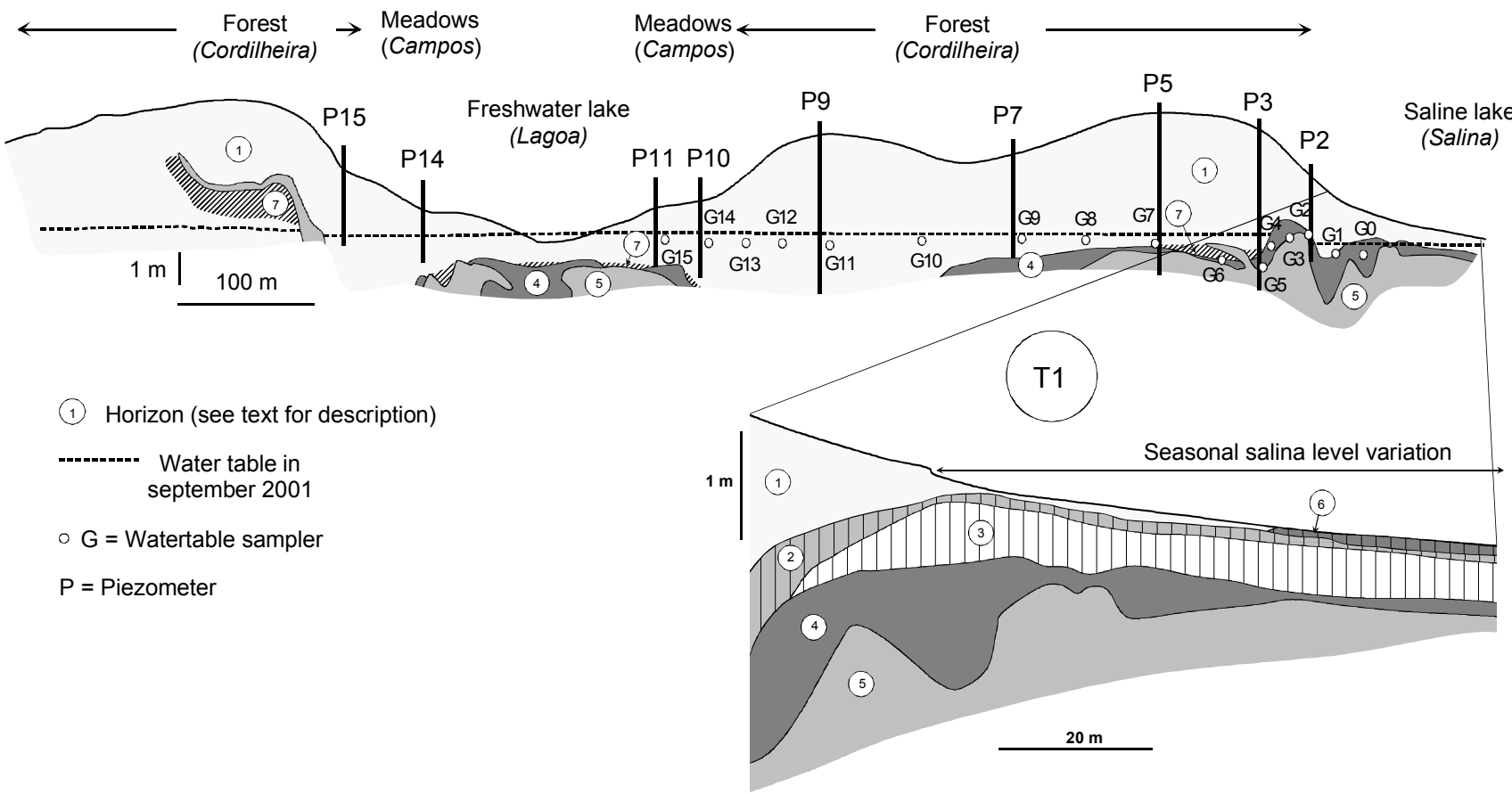

Fig. 4 - Transect T1: piezometers, watertable samplers and distribution of the main horizons.

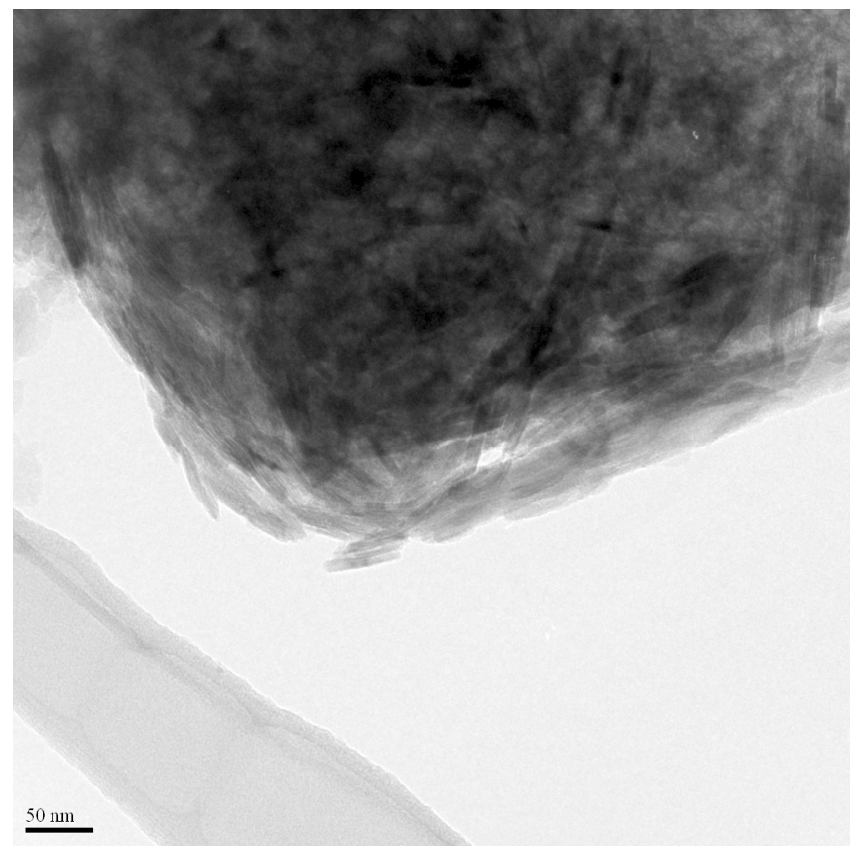

Fig. 5 - Transmission electron micrograph of sample from horizon 5 showing amorphous silica-rich phase with Fe-illite. 

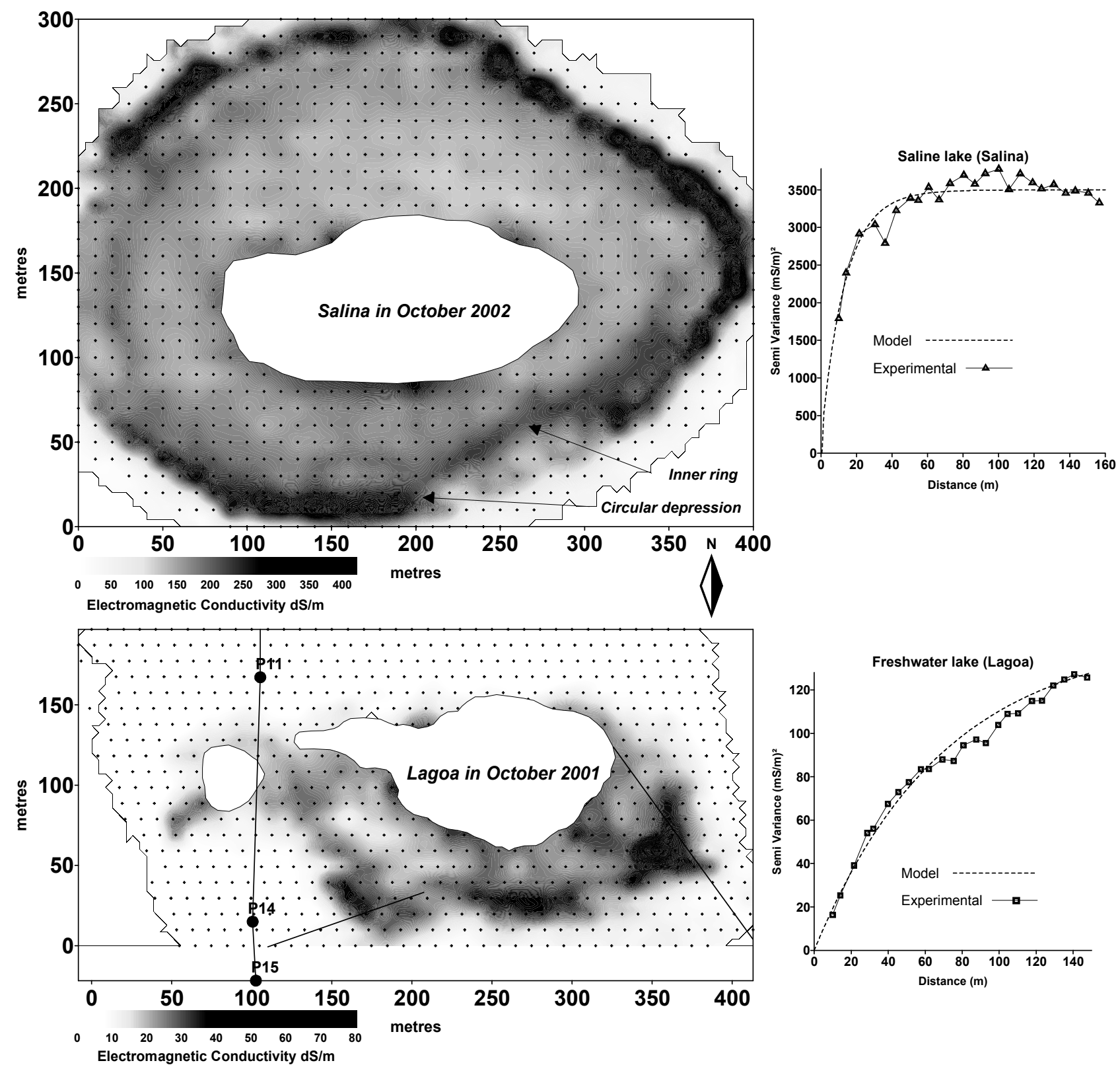

Fig. 6 - Experimental variogram, fitted model and Electromagnetic Conductivity $\left(\mathrm{EC}_{\mathrm{m}}\right)$ kriged map around the salina and lagoa. 

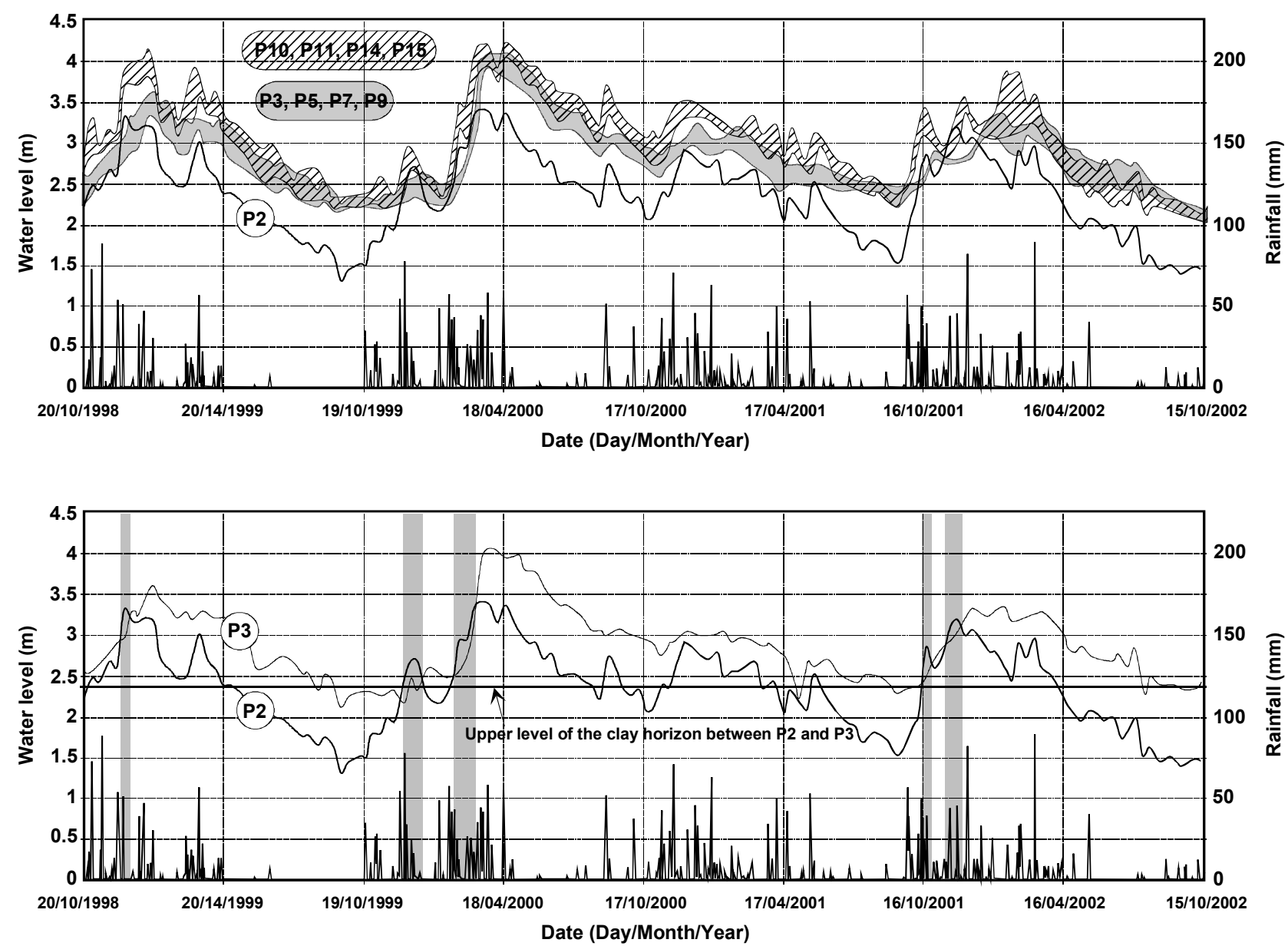

Fig. 7 - Rainfall and water level fluctuations from October 1998 to November 2002 along T1. Upper graph: 3 groups of piezometers are discriminated. Lower graph: Water level fluctuations in P2 and P3 showing inflow from P3 to P2. Short periods of possible back propagation of saline water (P2) into the fresh water aquifer (P3) are highlighted in grey. 

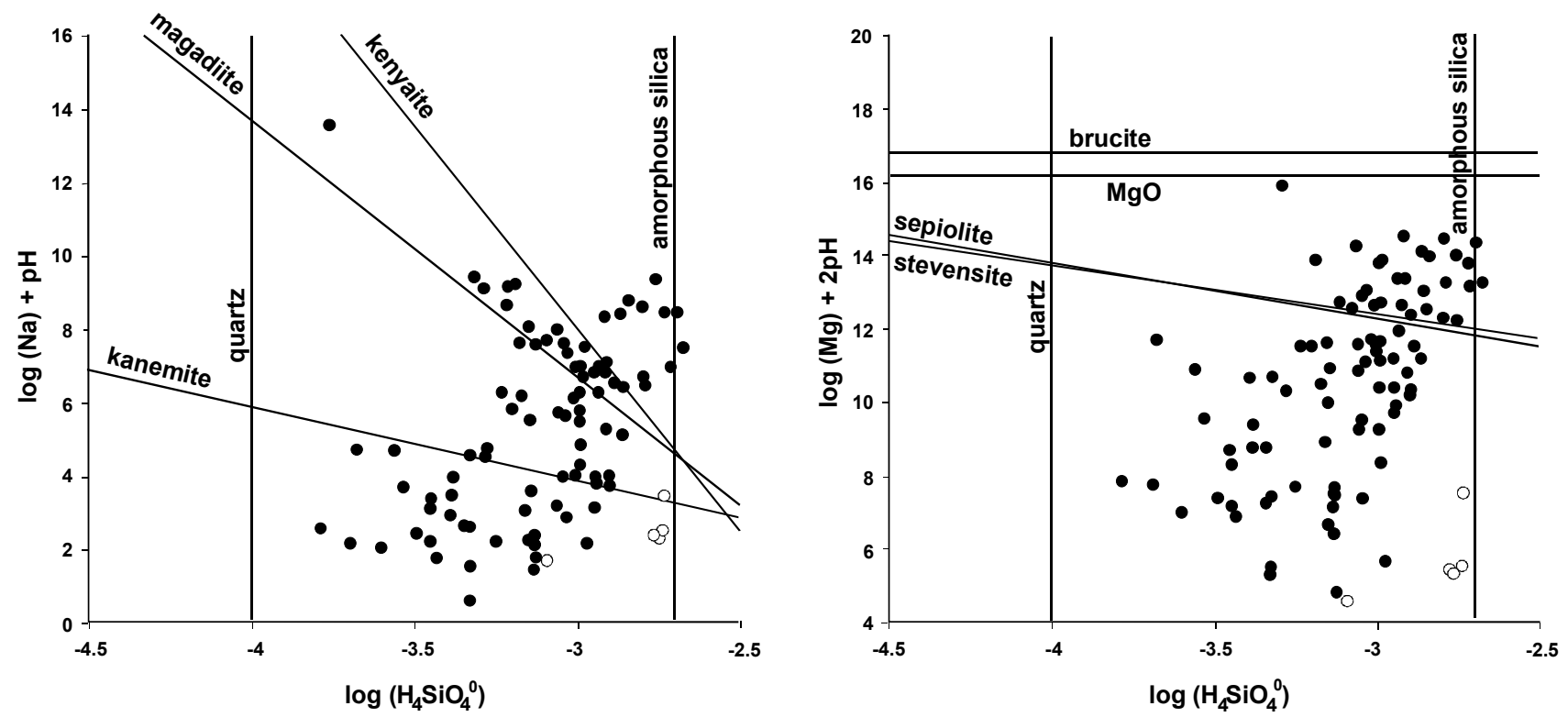

Fig. 8 - Saturation diagrams for $\mathrm{Na}$ - and $\mathrm{Mg}$-silicates. Open circle are acidic samples from the water sampler G6. 

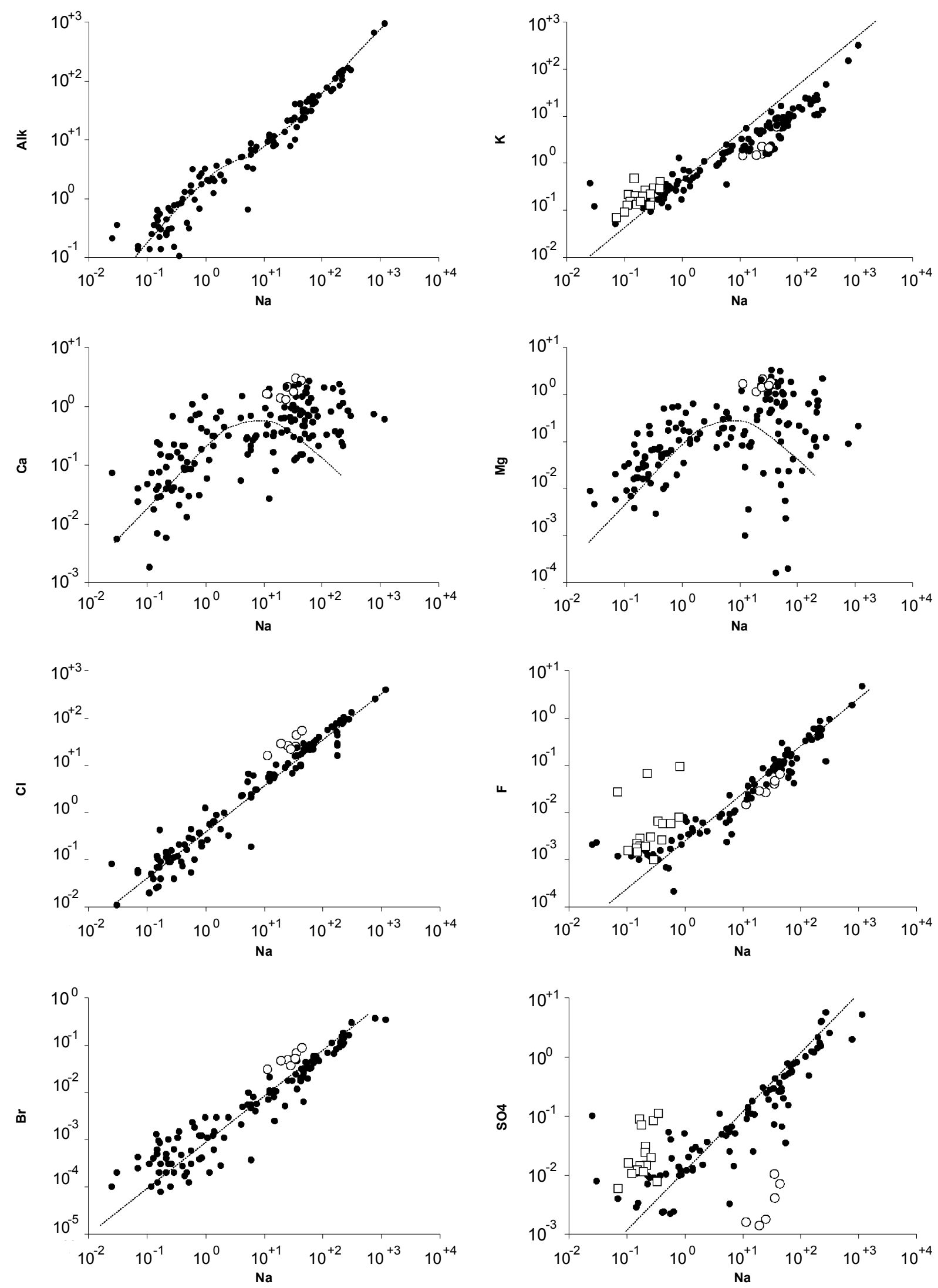

Fig. 9 - Concentration diagram against $\mathrm{Na}$ for the major elements (in $\mathrm{mM}$ ). Open circle are acidic samples from G6. On the plot for $\mathrm{K}, \mathrm{F}$ and $\mathrm{SO}_{4}$, squares are samples collected in and around the lagoa. The dotted line is the simulation of evaporation activating the possible precipitation of calcite and stevensite. 

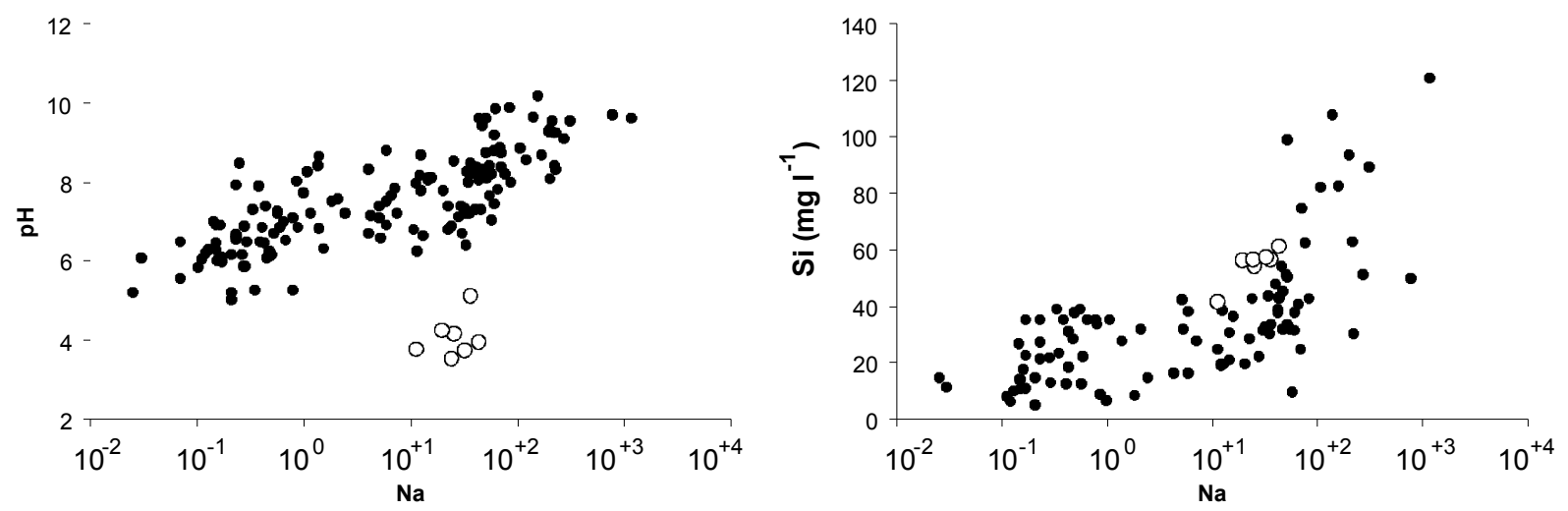

Fig. 10 - The relation of $\mathrm{pH}$ to $\mathrm{Na}$ and the plot of abundances of $\mathrm{Si}$ against $\mathrm{Na}$ for groundwater and surface water. Open circle are acidic samples from G6.
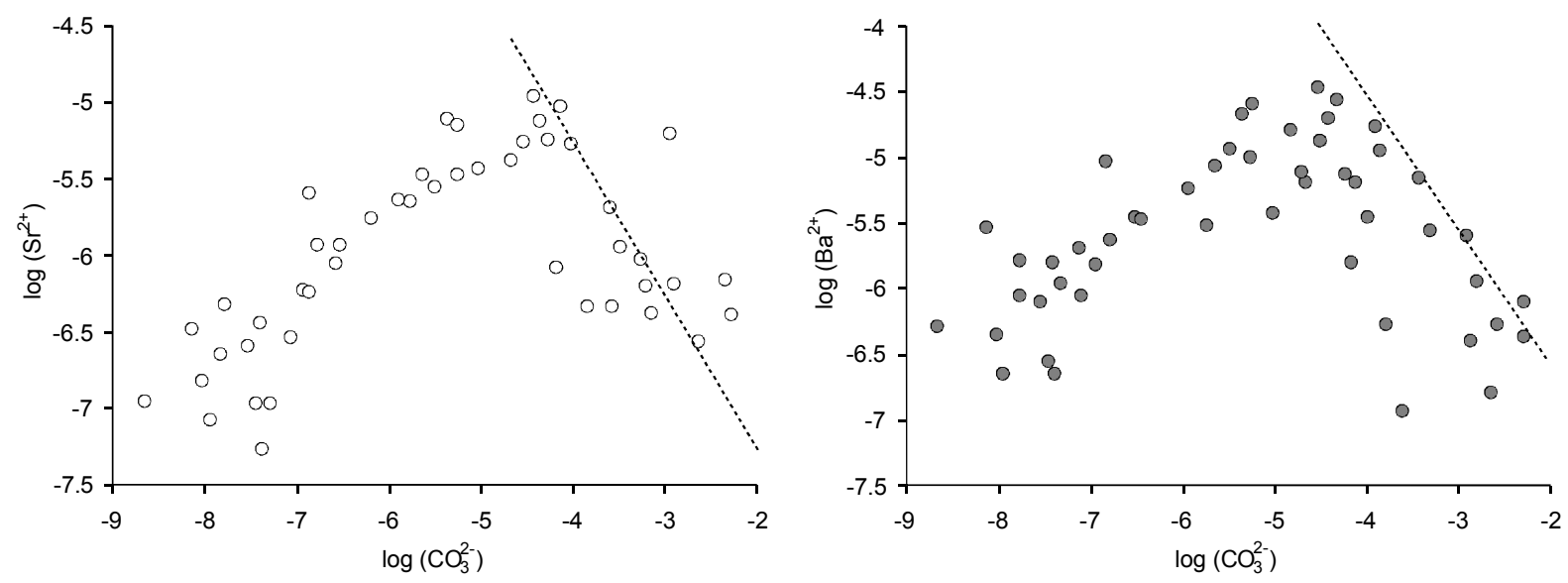

Fig. 11 - Saturation diagram for strontianite $\left(\mathrm{SrCO}_{3}\right)$ and witherite $\left(\mathrm{BaCO}_{3}\right)$. 

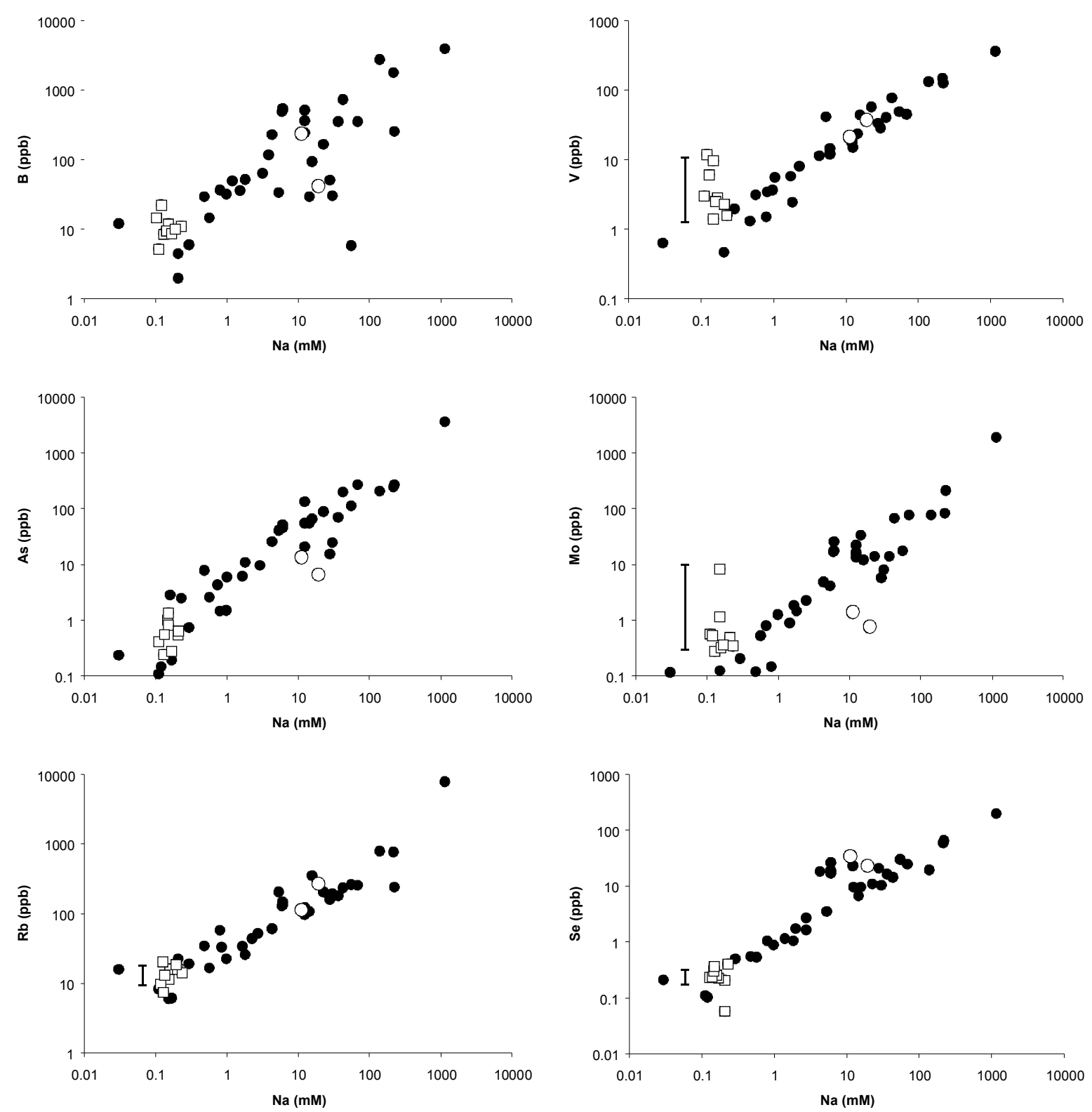

Fig. 12 - Plots of abundances of some minor elements against $\mathrm{Na}$ for waters collected along the transect T1. Samples from G6 (open circles) and around the lagoa (squares) are distinguished from the rest of the sampling (closed circles). Vertical bars are relative enrichments in the lagoa waters used for ' $\mathrm{x}$ ' axis of Fig. 14. 

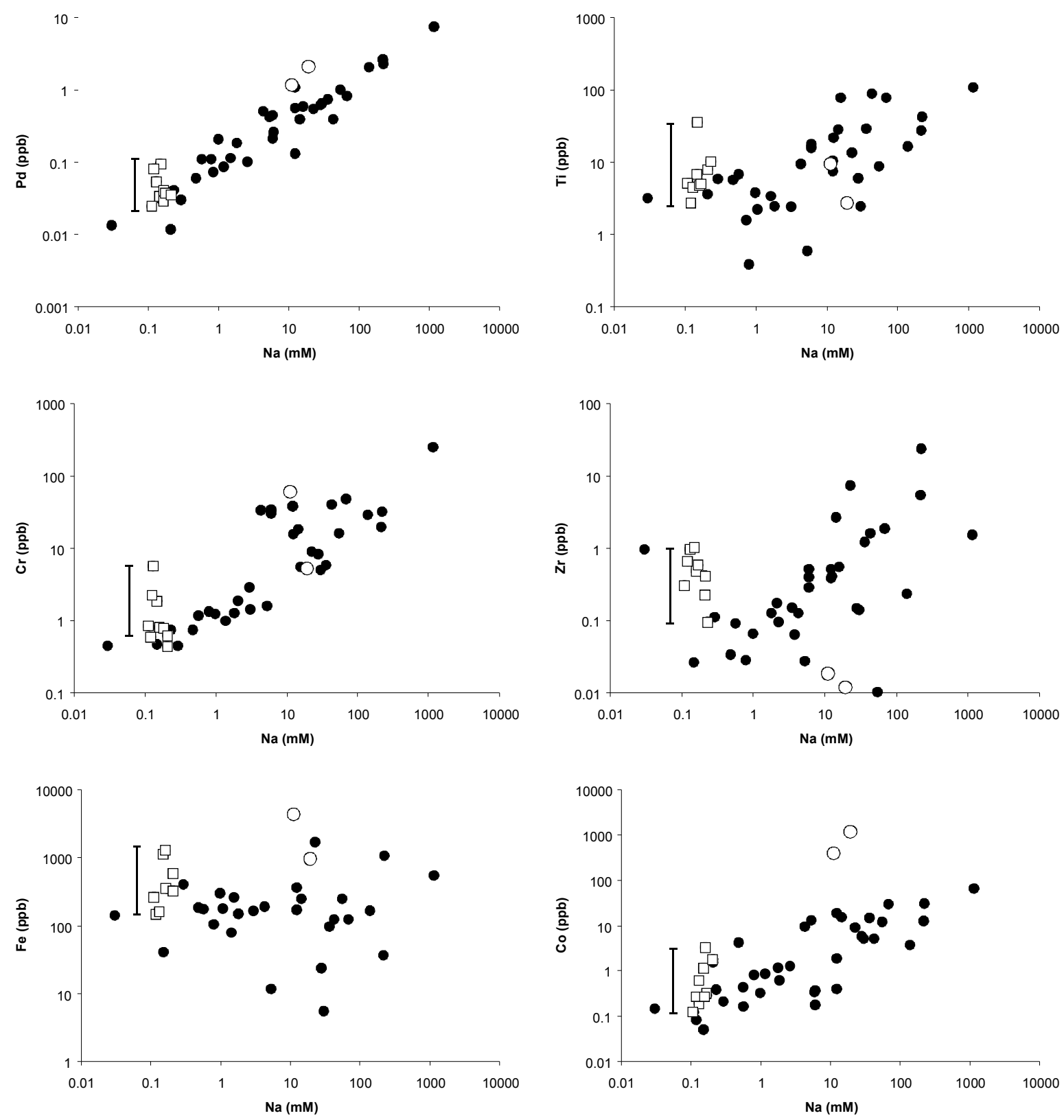

Fig. 12 -Continued. 

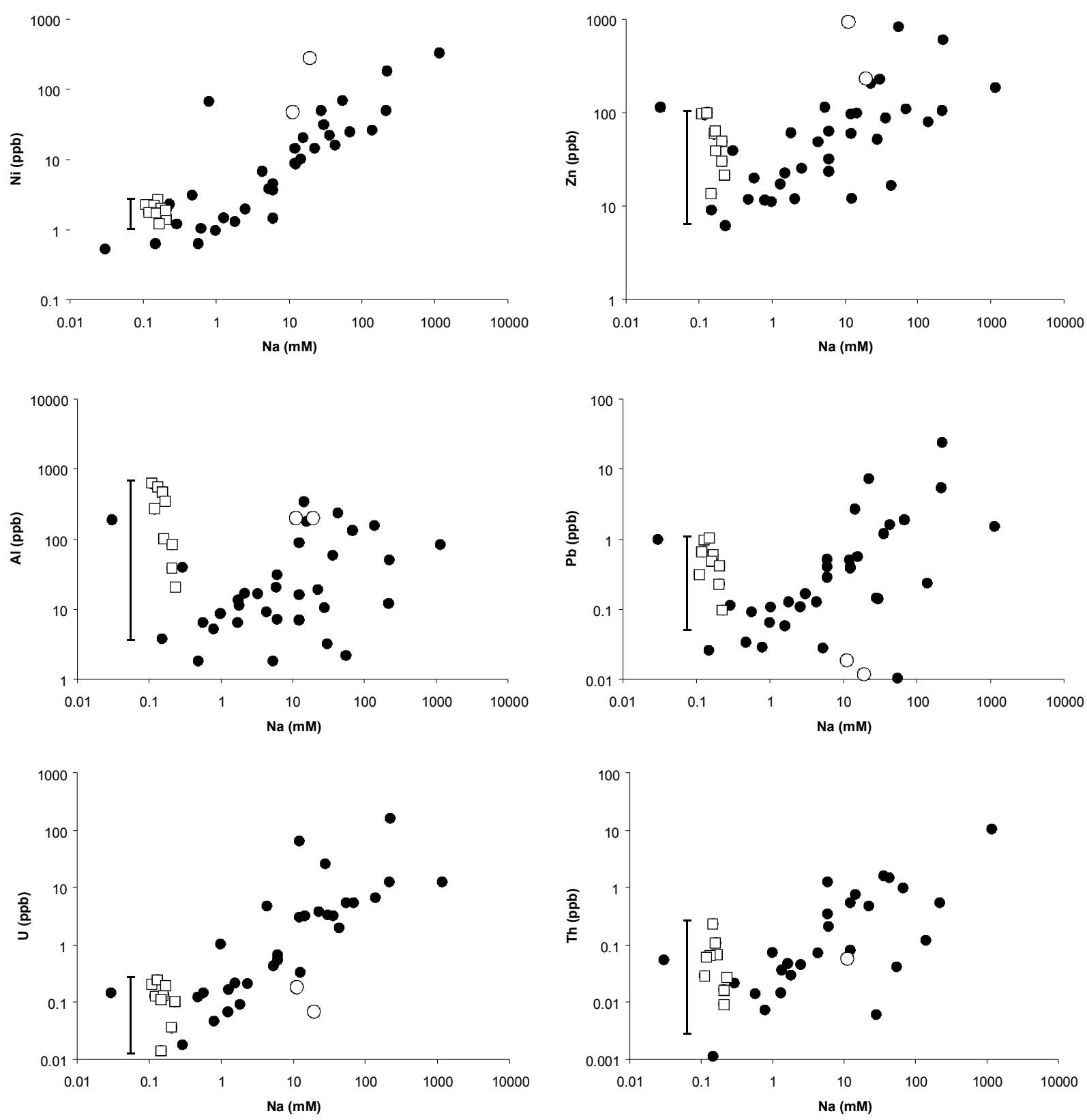

Fig. 12 -Concluded. 


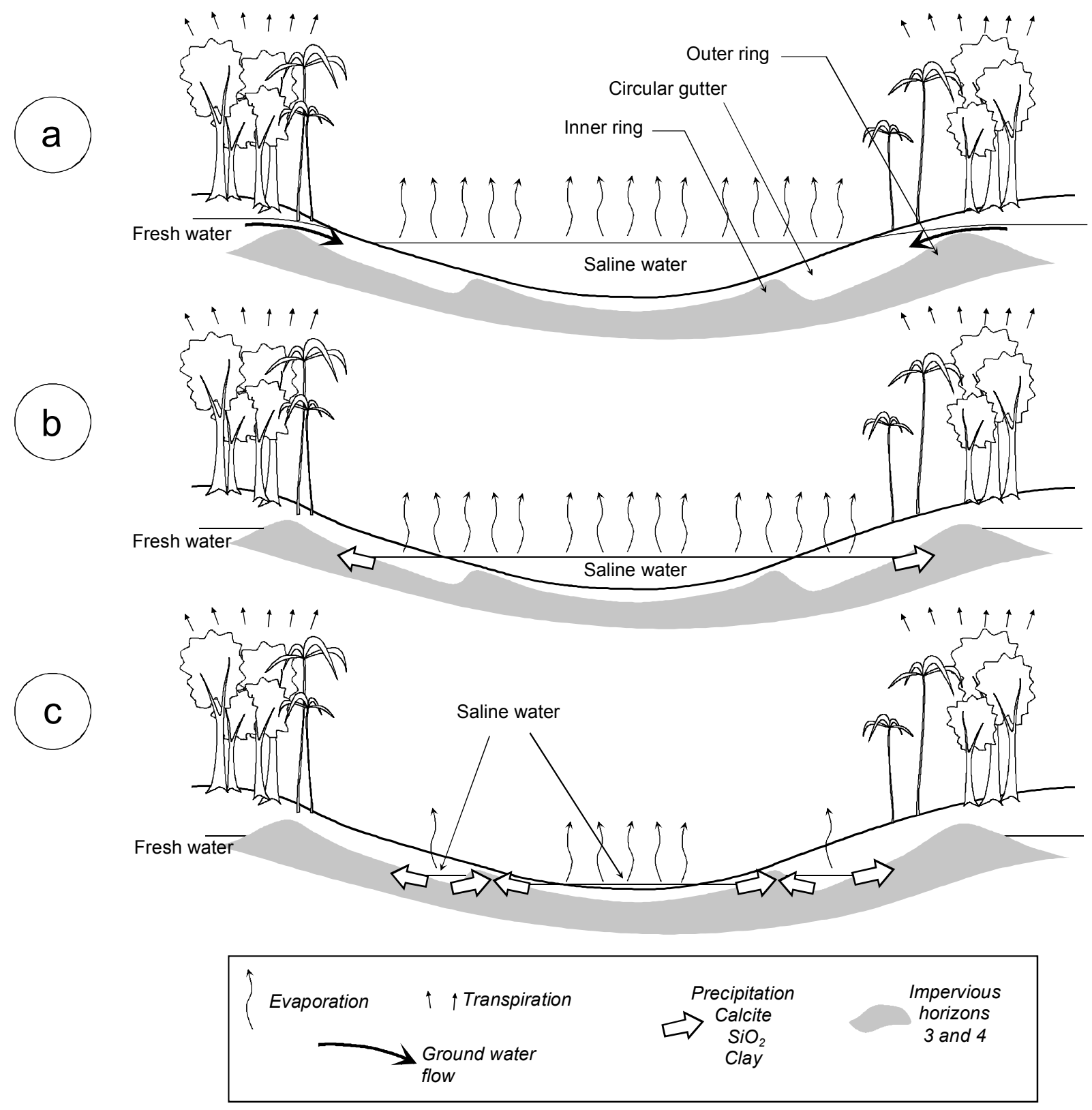

Fig. 13 - Present day hydrological functioning of a saline lake in the Pantanal of Nhecolândia. (a) wet season: inflow from the fresh groundwater system to the saline lake; (b) dry season: disconnection between fresh and saline groundwater at the outer ring. Chemical precipitations occur at the shore of the lake, strengthening the rise of horizons 4 and 5 (Fe-illite, amorphous silica and calcite). Trioctahedral Mg-rich smectites (saponite and stevensite) precipitate at topsoil; (c) during severe drought or at the very end of the dry season: disconnection between the circular gutter and the centre of the saline lake. The above mentioned chemical precipitations occur also at the inner ring. 


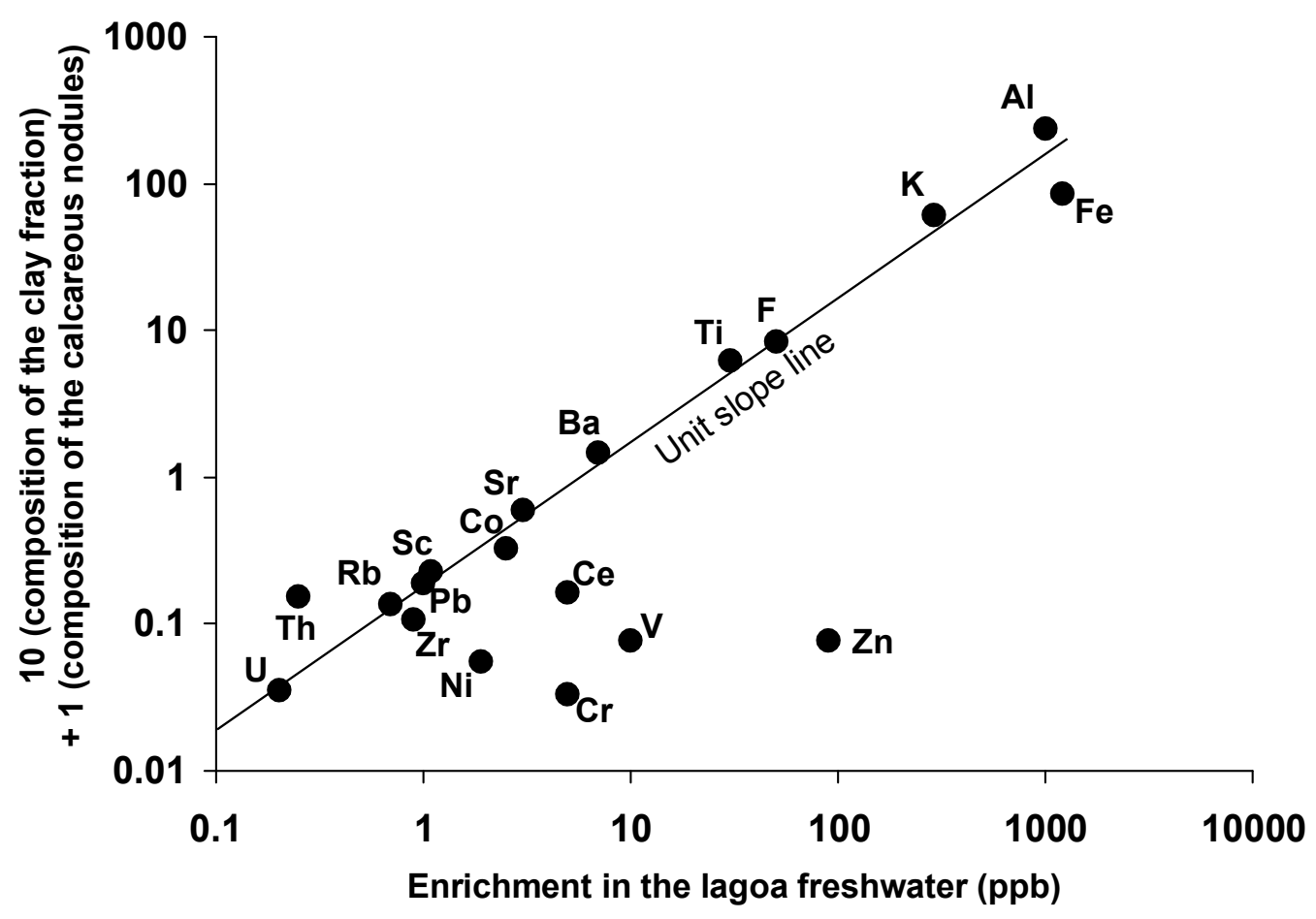

Fig. 14 - A linear combination of the composition of the clay fraction and calcareous nodules (10 Clay + Calc.) against the enrichment in the lagoa water (estimated from the concentration diagrams on Fig. 9 and 12). 
Table 1. Descriptive statistics of the major ions, silica and DOC.

\begin{tabular}{|c|c|c|c|c|c|c|}
\hline $\begin{array}{l}\text { Variable } \\
\left(\text { eq } 1^{-1}\right)\end{array}$ & Unit & $\begin{array}{l}\text { Average } \\
\text { value }\end{array}$ & Minimum & Maximum & $\begin{array}{c}\text { Variance } \\
v^{(a)}\end{array}$ & $\begin{array}{l}\text { Standard } \\
\text { deviation }\end{array}$ \\
\hline $\mathrm{pH}$ & - & 7.49 & 3.77 & 10.18 & 1.86 & 1.36 \\
\hline Carb. Alk. & $\left(\right.$ eq $\left.^{-1}\right)$ & $0.36510^{-1}$ & $-0.4510^{-3}$ & 0.941 & $0.12210^{-1}$ & 0.110 \\
\hline $\mathrm{K}^{+}$ & $\left(\right.$eq $\left.1^{-1}\right)$ & $0.86110^{-2}$ & $0.50010^{-4}$ & 0.317 & $0.10710^{-2}$ & $0.32710^{-1}$ \\
\hline $\mathrm{Na}^{+}$ & $\left(\right.$eq $\left.^{-1}\right)$ & $0.54510^{-1}$ & $0.25010^{-4}$ & 1.160 & $0.19710^{-1}$ & 0.140 \\
\hline $\mathrm{Ca}^{2+}$ & $\left(\right.$ eq $\left.1^{-1}\right)$ & $0.25310^{-3}$ & $0.10010^{-5}$ & $0.14710^{-2}$ & $0.84010^{-7}$ & $0.29010^{-3}$ \\
\hline $\mathrm{Mg}^{2+}$ & $\left(\right.$ eq $\left.^{-1}\right)$ & $0.17710^{-3}$ & $0.50010^{-6}$ & $0.16410^{-2}$ & $0.92210^{-7}$ & $0.30410^{-3}$ \\
\hline $\mathrm{Cl}^{-}$ & $\left(\right.$eq $\left.^{-1}\right)$ & $0.22210^{-1}$ & $0.1110^{-4}$ & 0.393 & $0.24210^{-2}$ & $0.49210^{-1}$ \\
\hline $\mathrm{SO}_{4}{ }^{2-}$ & $\left(\right.$ eq $\left.1^{-1}\right)$ & $0.20710^{-3}$ & $0.50010^{-6}$ & $0.27710^{-2}$ & $0.22510^{-6}$ & $0.47510^{-3}$ \\
\hline $\mathrm{F}^{-}$ & $\left(\right.$eq $\left.1^{-1}\right)$ & $0.14710^{-3}$ & $0.21710^{-6}$ & $4.73710^{-3}$ & $0.24010^{-3}$ & $0.49010^{-3}$ \\
\hline $\mathrm{Br}^{-}$ & $\left(\right.$eq $\left.^{-1}\right)$ & $0.03210^{-3}$ & $0.12510^{-6}$ & $0.37310^{-3}$ & $0.39210^{-5}$ & $0.62610^{-4}$ \\
\hline $\mathrm{SiO}_{2}$ & $\left(\mathrm{~mol} \mathrm{l}^{-1}\right)$ & $0.27410^{-1}$ & $0.710^{-3}$ & 0.121 & $1.27510^{-6}$ & $0.95310^{-3}$ \\
\hline DOC & $\mathrm{mg} \mathrm{l}^{-1}$ & 87.89 & 5.66 & 476 & 15888.33 & 126.05 \\
\hline
\end{tabular}

(a) $\quad v=\frac{1}{n} \sum_{i=1}^{n}\left(x_{i}-\bar{x}\right)^{2} \quad$ with $\quad \bar{x}=\frac{1}{n} \sum_{i=1}^{n} x_{i}$ 
Table 2 - Correlation matrix of the major ions, $\mathrm{pH}$, Electrical Conductivity and Silica

\begin{tabular}{|c|c|c|c|c|c|c|c|c|c|c|c|c|}
\hline & $\mathrm{pH}$ & E.C. & Alc. & $\mathrm{F}$ & $\mathrm{Cl}$ & $\mathrm{Br}$ & $\mathrm{SO} 4$ & $\mathrm{Ca}$ & $\mathrm{Mg}$ & $\mathrm{Na}$ & $\mathrm{K}$ & $\mathrm{Si}$ \\
\hline $\mathrm{pH}$ & 1 & 0.475 & 0.395 & 0.399 & 0.421 & 0.480 & 0.466 & 0.095 & -0.251 & 0.430 & 0.362 & 0.510 \\
\hline E.C. & & 1 & 0.978 & 0.984 & 0.995 & 0.958 & 0.914 & 0.118 & 0.099 & 0.994 & 0.960 & 0.781 \\
\hline Alc. & & & 1 & 0.998 & 0.986 & 0.898 & 0.851 & 0.057 & 0.018 & 0.994 & 0.996 & 0.674 \\
\hline $\mathrm{F}$ & & & & 1 & 0.990 & 0.910 & 0.861 & 0.054 & 0.029 & 0.997 & 0.991 & 0.696 \\
\hline $\mathrm{Cl}$ & & & & & 1 & 0.953 & 0.894 & 0.120 & 0.105 & 0.997 & 0.974 & 0.758 \\
\hline $\mathrm{Br}$ & & & & & & 1 & 0.950 & 0.223 & 0.197 & 0.937 & 0.865 & 0.822 \\
\hline SO4 & & & & & & & 1 & 0.207 & 0.149 & 0.892 & 0.804 & 0.737 \\
\hline $\mathrm{Ca}$ & & & & & & & & 1 & 0.533 & 0.087 & 0.034 & 0.160 \\
\hline $\mathrm{Mg}$ & & & & & & & & & 1 & 0.056 & 0.005 & 0.242 \\
\hline $\mathrm{Na}$ & & & & & & & & & & 1 & 0.983 & 0.728 \\
\hline K & & & & & & & & & & & 1 & 0.651 \\
\hline $\mathrm{Si}$ & & & & & & & & & & & & 1 \\
\hline
\end{tabular}


Table 3. Singular values of the Principal Component Analysis (PCA) carried out on major and minor elements, $\mathrm{pH}, \mathrm{EC}$ and DOC.

\begin{tabular}{|c|c|c|}
\hline axis & $\begin{array}{c}\% \text { of the } \\
\text { variance } v^{(a)}\end{array}$ & $\begin{array}{c}\% \text { of the variance } \\
\text { cumulated }\end{array}$ \\
\hline 1 & 56.5 & 56.5 \\
\hline 2 & 13.8 & 70.3 \\
\hline 3 & 9.5 & 79.8 \\
\hline 4 & 5.5 & 85.3 \\
\hline 5 & 4.4 & 89.7 \\
\hline
\end{tabular}

(a) see Table 1 . 